NBER WORKING PAPER SERIES

\title{
THE FORGOTTEN HISTORY OF DOMESTIC DEBT
}

\author{
Carmen M. Reinhart \\ Kenneth S. Rogoff \\ Working Paper 13946 \\ http://www.nber.org/papers/w13946
NATIONAL BUREAU OF ECONOMIC RESEARCH
1050 Massachusetts Avenue
Cambridge, MA 02138
April 2008

The authors are grateful to Vincent Reinhart, John Singleton, and seminar participants at Columbia, Harvard, and Maryland universities for useful comments and suggestions and to Ethan Ilzetzki for excellent research assistance. The views expressed herein are those of the author(s) and do not necessarily reflect the views of the National Bureau of Economic Research.

NBER working papers are circulated for discussion and comment purposes. They have not been peerreviewed or been subject to the review by the NBER Board of Directors that accompanies official NBER publications.

(C) 2008 by Carmen M. Reinhart and Kenneth S. Rogoff. All rights reserved. Short sections of text, not to exceed two paragraphs, may be quoted without explicit permission provided that full credit, including (c) notice, is given to the source. 
The Forgotten History of Domestic Debt

Carmen M. Reinhart and Kenneth S. Rogoff

NBER Working Paper No. 13946

April 2008

JEL No. E6,F3,N0

\begin{abstract}
There is a rich scholarly literature on sovereign default on external debt. Comparatively little is known about sovereign defaults on domestic debt. Even today, cross-country data on domestic public debt remains curiously exotic, particularly prior to the 1980s. We have filled this gap in the literature by compiling a database on central government public debt (external and domestic). The data span 1914 to 2007 for most countries, reaching back into the nineteenth century for many. Our findings on debt sustainability, sovereign defaults, the temptation to inflate, and the hierarchy of creditors only scratch the surface of what the domestic public debt data can reveal. First, domestic debt is big -- for the 64 countries for which we have long time series, domestic debt accounts for almost two-thirds of total public debt. For most of the sample, this debt carries a market interest rate (except for the financial repression era between WWII and financial liberalization). Second, the data go a long ways toward explaining the puzzle of why countries so often default on their external debts at seemingly low debt thresholds. Third, domestic debt has largely been ignored in the vast empirical work on inflation. In fact, domestic debt (a significant portion of which is long term and non-indexed) is often much larger than the monetary base in the run-up to high inflation episodes. Last, the widely-held view that domestic residents are strictly junior to external creditors does not find broad support.
\end{abstract}

\author{
Carmen M. Reinhart \\ University of Maryland \\ School of Public Policy and Department of Economics \\ 4105 Van Munching Hall \\ College Park, MD 20742 \\ and NBER \\ creinhar@umd.edu \\ Kenneth S. Rogoff \\ Thomas D Cabot Professor of Public Policy \\ Economics Department \\ Harvard University \\ Littauer Center 232 \\ Cambridge, MA 02138-3001 \\ and NBER \\ krogoff@harvard.edu
}




\section{Introduction}

This paper is as much an exercise in archeology as in economics. We have unearthed a vast trove of historical time-series data on domestic public debt for 64 countries ranging back to 1914. Our key sources are publications of the now-defunct League of Nations, including updates until the early 1980s by its successor, the United Nations. We also make use of national sources and work by scholars to supplement, cross-check and extend the data, both back before 1914 for some countries plus forward to the present for most. Although it may come as quite a surprise to most readers that historical time series on domestic debt should be exotic for so many countries, it is. This is in contrast to external sovereign debt, on which there is a vast literature. ${ }^{1}$ We are not aware of any academic or policy study that uses similar data, certainly not one encompassing such a long time period and so many countries.

Indeed, historical data on domestic (internal) government debt has been ignored for so long that many observers have come to believe that the issuance boom of the early 2000s is something entirely new and different. ${ }^{2}$ This perspective is based on the belief that, historically, domestic government debt played only a minor role in the public finances of most developing and post-conflict countries. ${ }^{3}$ The new data set thoroughly dispels this notion. Our key findings can be summarized as follow:

\footnotetext{
${ }^{1}$ Domestic public debt is issued under home legal jurisdiction. In most countries, over most of their history, it has been denominated in the local currency and held mainly by residents. By the same token, the overwhelming majority of external public debt—debt under the legal jurisdiction of foreign governmentshas been denominated in foreign currency and held by foreign residents. Theoretical models that try to explain default include Eaton and Gersovitz (1981) and Bulow and Rogoff (1989). Empirical studies of external debt that range from in-depth case studies (such as the classics by Winkler, 1928, or Wynne, 1951) to systematic cross-country analysis (Bordo and Eichengreen, 1999, Sturzenegger and Zettelmeyer, 2006 and Tomz, 2007). Eichengreen (1991) provides an authoritative summary of the early literature.

${ }^{2}$ See for example, the IADB 2006 annual report, or the April 2007 IMF Global Financial Stability Report.

${ }^{3}$ See for example, Eichengreen and Hausman (1999), who mainly focus on the post 1980 period.
} 
First, domestic debt is large - for the 64 countries for which we have long time series, domestic debt averages almost two-thirds of total public debt; for most of the sample these debts typically carried a market interest rate, except for the era of financial repression after World War II. Second, recognizing the significance of domestic debt goes a long way toward explaining the puzzle of why many countries default on (or restructure) their external debts at seemingly low debt thresholds. In fact, when heretofore ignored domestic debt obligations are taken into account, fiscal duress at the time of default is often revealed to be quite severe. ${ }^{4} \mathrm{~A}$ third and related point is that domestic debt may also explain the paradox of why some governments seem to choose inflation rates far above any level that might be rationalized by seignorage revenues leveraged off the monetary base (e.g., as in Cagan’s classic, 1956, article on postwar hyperinflations). Although domestic debt is largely ignored in the vast empirical literature on high and hyperinflation, we find that there are many cases where the hidden overhang of domestic public debt was at least the same order of magnitude as base money, and sometimes a large multiple. ${ }^{5}$

Last, our paper offers a first attempt to catalogue episodes of overt default on and rescheduling of domestic public debt across more than a century. This phenomenon appears to be somewhat rarer than external default, but far too common to justify the extreme assumption that governments always honor the nominal face value of domestic debt. When overt default on domestic debt does occur, it appears to occur under

\footnotetext{
${ }^{4}$ This puzzling “debt intolerance” is examined by Reinhart, Rogoff, and Savastano (2003).

${ }^{5}$ See Fischer, Sahay, and Vegh (2002) for an excellent treatise on this subject (and the classic papers that are cited therein). A few theoretical treatments (for example Calvo, 1989) have recognized the potential significance of nominal domestic debt. Yet, since many researchers have long believed domestic debt to be relatively small and unimportant, the incentives to inflate it away have received scant attention in the empirical literature.
} 
situations of greater duress than for pure external defaults—-both in terms of an implosion of output and marked escalation of inflation. It is important to note that we do not here catalogue episodes of major de facto partial defaults, say through a sharp unexpected increase in financial repression (e.g., of the type India and China still impose today).

The rest of the paper proceeds as follows. Since our new public debt database is central to our analysis, we begin by describing some of its key features. Specifically, we focus on four broad areas: the composition of public debt (domestic versus external); the structure of domestic debt by maturity; the interest rates on domestic and external debt; and, lastly, what little is known of its currency composition. Further details are discussed in the Appendices.

Section III introduces our approach to cataloguing defaults on domestic public debt. Such defaults typically leave few footprints in the mainstream international or business press and are therefore much more difficult to detect than external defaults (which our database comprehensively catalogues). In section IV, we look at the potential role of domestic debt during episodes of external default. Section V explores the connection between high inflation and domestic debt in emerging markets and postconflict countries. Section VI attempts to shed light on the issue of who gets heavily defaulted on more often, domestic or foreign residents.

In our conclusion, we raise the question of whether the difficulties in unearthing domestic public debt data should be addressed by an international agency that coordinates greater transparency across sovereign debt issuers. The League of Nations once enforced such reporting, although the results were under-publicized and subsequently forgotten. Should not today's multilateral lending institutions, such as the International Monetary 
Fund and the World Bank, be able to do the same today, if not better? The IMF's Special Data Dissemination Standard (SDDS) takes a step in that direction but only the most recent figures appear and debt categories vary substantially by country. Absent a borrowing history, it is impossible to conduct any meaningful credit analysis.

\section{Domestic Public Debt: Some Features}

Unquestionably, the single most remarkable feature of our cross-country data set is its apparent uniqueness. Until now, obtaining comprehensive long-term time series on domestic debt has been extremely difficult for most countries. Even for the relatively rich countries, the OECD database only goes back to 1980, and constructing long-term time series from national sources is far less straightforward than one might imagine. Outside the OECD countries, the dearth of data is stunning.

Only recently, a few groups of scholars have begun constructing data for the contemporary period. Reinhart, Rogoff and Savastano (2003) draw on national sources to develop a data set for selected developing countries and emerging markets covering the years 1990 to 2002. More recently, Jeanne and Guscina (2006) provide detailed data on domestic debt for nineteen important emerging markets for 1980 to 2005. Cowan, LevyYeyati, Panizza and Sturzenegger (2006) provide data for all the countries in the Western Hemisphere from 1980 (or 1990) to 2004. ${ }^{6}$

Figure 1 plots the share of domestic debt in total public debt for 1900 to 2006, which averaged between 40 and 80 percent of total debt. See data appendix for data availability by country. The figures in this chart are simple averages across countries, but these ratios are also fairly representative for many of the emerging markets in the

\footnotetext{
${ }^{6}$ Reinhart and Rogoff (2008) describe a companion database covering a broad range of related variables, including external debt, that we also draw upon here.
} 
sample (including now-rich countries when they were still emerging markets, such as Greece, Austria, and Spain). ${ }^{7}$ As the figure underscores, the data set here contains significant representation from every continent, not just for a handful of Latin American and European countries, as in most of the external debt literature.

Of course, the experience is diverse. For advanced economies, domestic debt accounts for the lion's share of public-sector liabilities. At the other extreme, in some emerging markets, especially in the 1980s and 1990s, domestic debt markets were dealt a brutal blow by many governments’ propensity to inflate-or hyperinflate. For instance, in the years following the hyperinflation of 1989 to 1990, domestic debt only accounted for 10 to 20 percent of Peru's public debt. Yet, this was not always so. As with many other countries in Latin America, the early (end of World War I) entries of the League of Nations data show that Peru's domestic debt then accounted for about two-thirds of public-sector debt. Indeed, the share was even higher in the 1950s, when the world's financial centers were not engaged in much external lending.

In addition to showing that the debt is large, the data also dispel the belief that until recently, emerging markets (and developing countries) had never been able to borrow long term. As Figure 2 shows, long-term debt constitutes a large share of the total debt stock over a significant part of the sample, at least for the period 1914 to 1959. (Over this sub-period, the League of Nations/UN database provides considerable detail on maturity structure.) It may come as a surprise to many readers (as it did to these authors) that modern bias towards short-term debt is a relatively recent phenomenon, evidently a product of the "inflation fatigue” of the 1970s and 1980s.

\footnotetext{
${ }^{7}$ Domestic public debt has never amounted to much in a few Latin American countries (Uruguay stands out in this regard), and public debt markets are virtually nonexistent in the CFA African countries (which originally were the Colonies françaises d'Afrique).
} 
Figure 1

Domestic Public Debt as a Share of Total Debt

Emerging market economies, 1900-2006

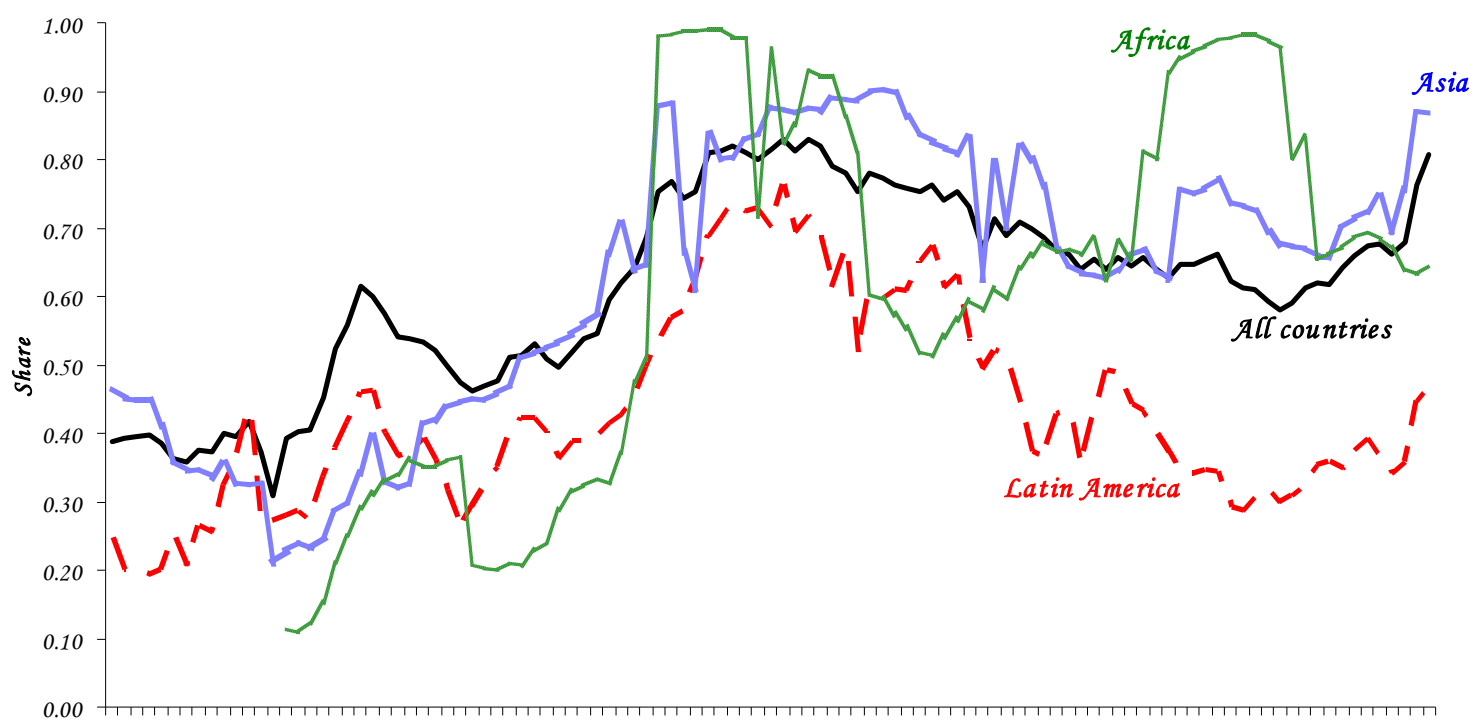

$\begin{array}{llllllllllllllllllllll}1900 & 1905 & 1910 & 1915 & 1920 & 1925 & 1930 & 1935 & 1940 & 1945 & 1950 & 1955 & 1960 & 1965 & 1970 & 1975 & 1980 & 1985 & 1990 & 1995 & 2000 & 2005\end{array}$

Advanced economies, 1900-2006

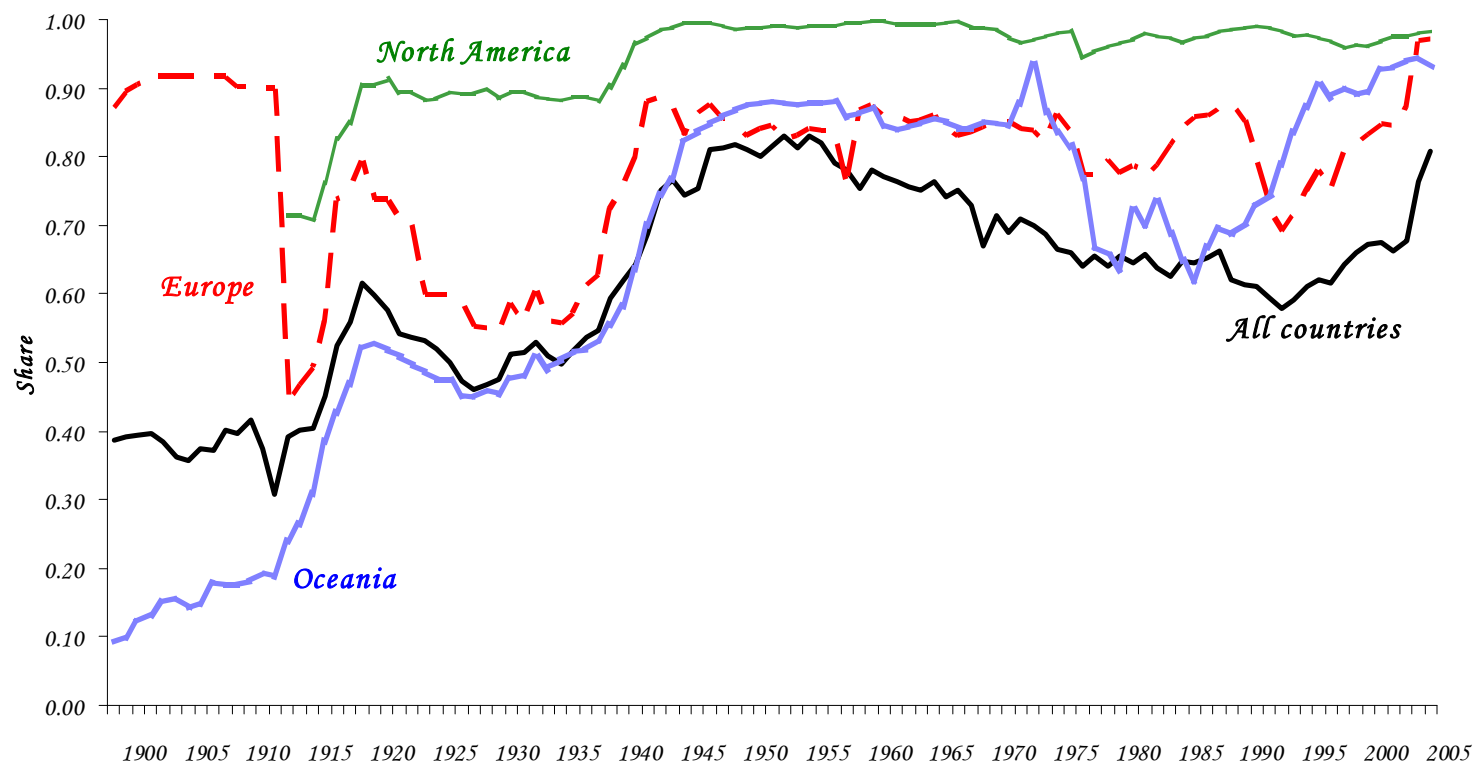

Sources: See Appendix II for domestic debt data; see Reinhart and Rogoff (2008) for external debt data. 
Figure 2. Share of Domestic De6t Which is Long-term, 1914-1959

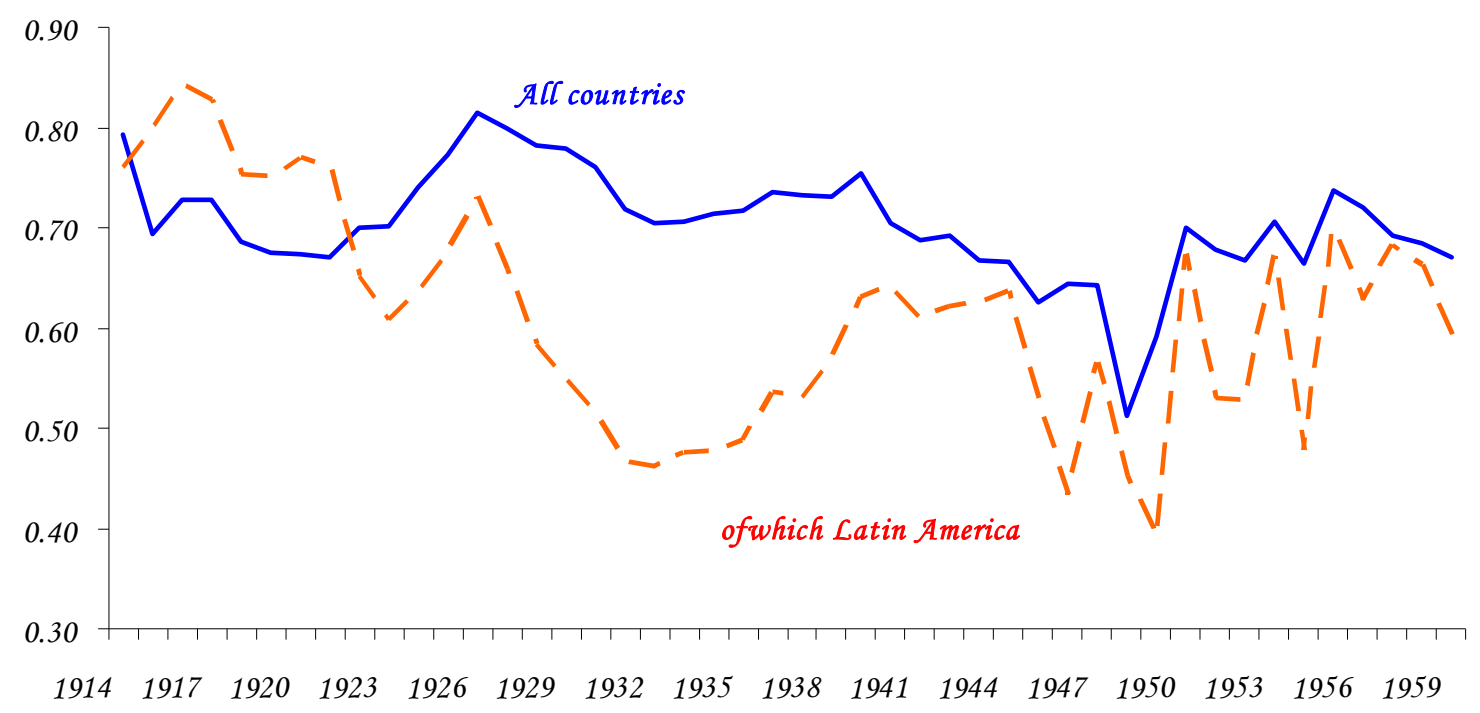

Sources: See appendices and sources cited therein.

Nor is the fact that many emerging markets are now paying market-oriented interest rates on domestic debt new. Of course, during the post-World War II era, many governments did repress domestic financial markets, with low deposit rate ceilings and high bank reserve requirements, among other devices. But in fact, interest rate data for the first half of the twentieth century shows that financial repression was neither so strong nor so universal. As Table 1 shows for the years 1928-1946, the period over which we have the best documentation, interest rates on domestic and external debt issues were relatively similar, supporting the notion that the debt was market determined.

A final issue is inflation or foreign currency indexation. Until very recently, most observers held that domestic public debt was mostly non-indexed local currency obligations. Most externally issued emerging market public debt was similarly viewed as 
Table 1. Interest Rates on Domestic and External Debt: 1928-1946

\begin{tabular}{|c|c|c|}
\hline \multirow[t]{2}{*}{ Country } & \multicolumn{2}{|c|}{ "Range of interest rates (in percent) } \\
\hline & Domestic debt issues & External debt issues \\
\hline Argentina & $3-6$ & $3 \frac{1}{1 / 2}-4^{1 / 2}$ \\
\hline Australia & $2-4$ & $33 / 8-5$ \\
\hline Austria & $4^{1 / 2-6}$ & 5 \\
\hline Belgium & $3^{1 / 2-5}$ & $3-7$ \\
\hline Bolivia & $1 / 4-8$ & $6-8$ \\
\hline Brazil & $4-7$ & $4-7$ \\
\hline Bulgaria & $4-61 / 2$ & $7-71 / 2$ \\
\hline Canada & $1-5^{1 / 2}$ & $1^{1 / 4}-51 / 2$ \\
\hline Chile & $1-8$ & $4 \frac{1 / 2-7}{2}$ \\
\hline Colombia & $3-10$ & $3-6$ \\
\hline Costa Rica & 6 & $5-71 / 2$ \\
\hline Denmark & $2^{1 / 2}-5$ & $4^{1 / 2-6}$ \\
\hline Ecuador & 3 & $4-8$ \\
\hline Egypt & $21 / 2-41 / 2$ & $3^{1 / 2-4}$ \\
\hline Finland & $4-51 / 2$ & $2^{1 / 2-7}$ \\
\hline Germany & $3^{1 / 2}-7$ & $5^{1 / 2-6}$ \\
\hline Greece & $3-9$ & $3-10$ \\
\hline Hungary & $31 / 2-5$ & $3-71 / 2$ \\
\hline India & $3-5^{1 / 2}$ & $3-51 / 2$ \\
\hline Italy & $3^{1 / 2-5}$ & No external debt \\
\hline Japan & $3^{1 / 2-5}$ & $4-61 / 2$ \\
\hline Netherlands & $2^{1 / 2-6}$ & No external debt \\
\hline New Zealand & $2^{1 / 2-4}$ & $2 \frac{1}{1 / 2}-5$ \\
\hline Nicaragua & 5 & $4-5$ \\
\hline Poland & $3-7$ & $3-7$ \\
\hline Portugal & $2.1-7$ & $3-4$ \\
\hline Romania & $3^{1 / 2-5}$ & $4-7$ \\
\hline South Africa & $3^{1 / 2-6}$ & $3^{1 / 2-6}$ \\
\hline Spain & $3^{1 / 2-6}$ & $3-4$ \\
\hline Sweden & $2^{1 / 2}-4^{1 / 2}$ & No external debt \\
\hline Thailand & $2 \frac{1}{2}-4 \frac{1}{2}$ & $4 \frac{1}{2}-7$ \\
\hline Turkey & $21 / 2-51 / 2$ & $61 / 2-71 / 2$ \\
\hline United Kingdom & $1 \frac{1}{2}-4$ & No marketable external debt \\
\hline United States & $1^{1 / 2}-2^{1 / 2}$ & No external debt \\
\hline Uruguay & $5-7$ & $3 \frac{1}{1 / 2}-6$ \\
\hline Venezuela & 3 & 3 \\
\hline
\end{tabular}

Notes: These are rates on domestic long-term debt, as it facilitates comparisons to external debt, which has a similar maturity profile. The higher interest rates are the most representative.

Source: United Nations (1948).

foreign currency denominated. ${ }^{8}$ Indeed, many observers viewed Mexico’s famous

issuance of dollar-linked domestic debt in the early 1990s (the so-called tesobonos) as a

\footnotetext{
${ }^{8}$ It should also be noted that until the past ten to fifteen years, most countries' external debt was largely public debt. Private external borrowing has become more significant only over the past couple decades; see Prasad et al. (2003). Arellano and Kocherlakota (2008) develop a model of the relationship between private debt and external government default.
} 
major innovation. In reality, Argentina issued domestic government bonds in the late 1800s that were denominated in pound sterling, and Thailand issued dollar-linked domestic debt in the 1960s (See Appendix Table 4 for sources). ${ }^{9}$

We summarize by noting that for most countries over most of history (notably including emerging markets), domestic debt has been large and highly significant. Nothing about the maturity structure or interest rates paid on these debts lends justification to the common practice of ignoring them in calculations of debt sustainability or inflation stability.

We acknowledge that our data set has important limitations. First, the data generally cover only central government debt. Of course, it would be desirable to have long time series on consolidated government debt, including state and local debt and guaranteed debt for quasi-public agencies. Furthermore, many central banks across the world issue debt on their own, often to sterilize foreign exchange intervention (See Calvo, 1991, on these "perilous" practices). Adding such data, of course, would only expand the perception of how important domestic public debt has been.

We now take up some important potential applications of this data.

\section{Cataloguing Defaults on Domestic Public Debt}

Theoretical models contain a wide range of assumptions about domestic public debt. The overwhelming majority of models simply assume that debt is always honored. These include models where deficit policy is irrelevant due to Ricardian equivalence (Barro, 1976), where domestic public debt is a key input in price-level determination through the government’s budget constraint (Woodford, 1995), and where generations

\footnotetext{
${ }^{9}$ Of course, during the early years of the interim war period, many countries pegged their currencies to gold (See Appendix Table 3).
} 
overlap (Diamond, 1965). There is a small literature that aims to understand why governments honor domestic debt at all (e.g., Persson and Tabellini, 2000, or Kotlikoff, Persson, and Svensson, 1988). However, the general assumption throughout the literature is, whereas governments may inflate away debt, outright defaults on domestic public debt are extremely rare. This is in stark contrast to the literature on external public debt, where the government's incentive to default is one of the main focuses of inquiry. In fact, our reading of the historical record is that overt de jure defaults on domestic public debt, while less common than external defaults, are hardly rare. Our data set includes 68 cases of overt default (compared to 250 post-1800 external debt defaults). These de jure defaults took place via a potpourri of mechanisms, ranging from forcible conversions, to lower coupon rates, to unilateral reduction of principal (sometimes in conjunction with a currency conversion), to suspensions of payments. Appendix Table 3 lists these episodes.

As we have already emphasized, our catalogue of domestic defaults is almost certainly a lower bound, as domestic defaults are far more difficult to detect than defaults on international debt. Even the widespread defaults on domestic debt during the 1930s Great Depression in both advanced and developing economies are not well documented. As a more recent example, consider Argentina. Between 1980 and 2001, Argentina defaulted three times on its domestic debt. The two defaults that coincided with defaults in external debt (1982 and 2001) did attract considerable international attention. However, the large-scale 1989 default, which did not involve a new default on external debt, is scarcely known outside Argentina. 
Why would a government refuse to pay its domestic public debt in full when it can simply inflate the problem away? One answer, of course, is that inflation causes distortions, especially to the banking system and the financial sector. Sometimes, the government may view repudiation as the lesser evil. The potential costs of inflation are especially problematic when the debt is relatively short term or indexed, since the government then has to inflate much more aggressively to achieve a significant real reduction in debt service payments. In other cases, such as the United States during the Great Depression, default (by abrogation of the gold clause in 1933) was a precondition for reinflating the economy through expansionary fiscal and monetary policy.

Of course, there are other forms of de facto default (besides inflation). The combination of heightened financial repression with rises in inflation was an especially popular form of default from the 1960s to the early 1980s. Brock (1989) makes the point that inflation and reserve requirements are positively correlated, particularly in Africa and Latin America. ${ }^{10}$ Interest rate ceilings combined with inflation spurts are also common. For example, during the 1972-1976 external debt rescheduling in India, interest rates (interbank) in India were 6.6 and 13.5 percent in 1973 and 1974, while inflation spurted to 21.2 and 26.6 percent. These episodes of de facto default through financial repression are not listed among our de jure credit-event dating. Only to the extent that inflation exceeds the 20 percent threshold we use to define an inflation crisis, do they count at all. $^{11}$

\footnotetext{
${ }^{10}$ Average reserve requirements for developing countries in his 1960 to early 1980 s sample ran at about 0.25 , more than three times the average for advanced economies.

${ }^{11}$ Another subtle type of default is illustrated by the Argentine government's treatment of its inflationindexed debt in 2007. Most impartial observers agree that Argentina's official inflation rate considerably understates actual inflation because of government manipulation. This represents a partial default on index-
} 
Clearly, the assumption embedded in many theoretical models that governments always honor the nominal face value of debt is a significant overstatement, particularly for emerging markets past and present. Nevertheless, we would also caution against reaching the opposite extreme conclusion, that governments can ignore powerful domestic stakeholders and simply default at will (de jure or de facto) on domestic debt. We will now proceed to explore some implications of the overhang of large domestic debt on external default and inflation.

\section{Domestic Debt and External Default: The Missing Link}

We begin by revisiting the conventional wisdom on external debt default and its implications for debt sustainability exercises and debt default thresholds. Indeed, in the 250 external debt default episodes in our database, it is clear that domestic debt loomed large across the vast majority of them. Table 2 gives the ratio of both external debt and total debt (including domestic and external liabilities) relative to government revenues on the eve of many of the nineteenth and twentieth centuries' most notable defaults. We normalize debt by government revenues because data on nominal GDP is sketchy or nonexistent for the nineteenth-century default episodes. (For many countries, standard sources such as Maddison, 2004, do not provide anything close to a continuous time series for GDP for the nineteenth century.) Exports, which usually have longer time series, are not the obvious benchmark once domestic debt is added to the calculus of debt sustainability.

linked debt by any reasonable measure, and it affects a large number of bondholders. Yet, Argentina's de facto domestic bond default has not registered heavily in the external press or with rating agencies. 
Table 2. Debt Ratios at the Time of Default: Selected Episodes

\begin{tabular}{cccc}
\hline \hline Country & Year of default & $\begin{array}{c}\text { External public debt/ } \\
\text { revenue }\end{array}$ & $\begin{array}{c}\text { Total public debt/ } \\
\text { revenue }\end{array}$ \\
\hline Mexico & 1827 & 1.55 & 4.20 \\
Spain & 1877 & 4.95 & 15.83 \\
Argentina & 1890 & 4.42 & 12.46 \\
Germany & 1932 & 0.64 & 2.43 \\
China & 1939 & 3.10 & 8.96 \\
Turkey & 1978 & 1.38 & 2.69 \\
Mexico & 1982 & 3.25 & 5.06 \\
Brazil & 1983 & 0.83 & 1.98 \\
Philippines & 1983 & 0.23 & 1.25 \\
South Africa & 1985 & 0.09 & 1.32 \\
Russia & 1998 & 3.90 & 4.95 \\
Pakistan & 1998 & 3.32 & 6.28 \\
Argentina & 2001 & 1.59 & 2.62 \\
\hline \hline
\end{tabular}

Sources: See Data Appendices I and II in Reinhart and Rogoff (2008).

Looking more broadly at our the sample, Figure 4 is based on the 89 episodes of external default over the period 1827 to 2003 where we have full data on external debt, total debt, and revenues. In all regions except Latin America, external debt accounts for less than half of total debt during the year a country defaults on external debt; for Latin America, the average ratio is higher, but still only 60 percent.

Thus, uncovering data on domestic debt suggests at least a partial answer to one of the most basic puzzles in the entire literature on international debt, emphasized by Bulow and Rogoff (1987) among others: Why do emerging market governments tend to default at such stunningly low levels of debt repayments and debts to GDP? Reinhart, Rogoff and Savastano (2003), for example, present evidence that “serial defaulters” tend to default at ratios of debt to GDP that are below the euro area's "Maastricht Treaty" upper bound of 60 percent. In fact, taking into account domestic public debt, the anomaly largely disappears. 
Figure 3. Pu6lic De6t-to-Revenue Ratios During External Default: 89 Episodes, 1827-2003

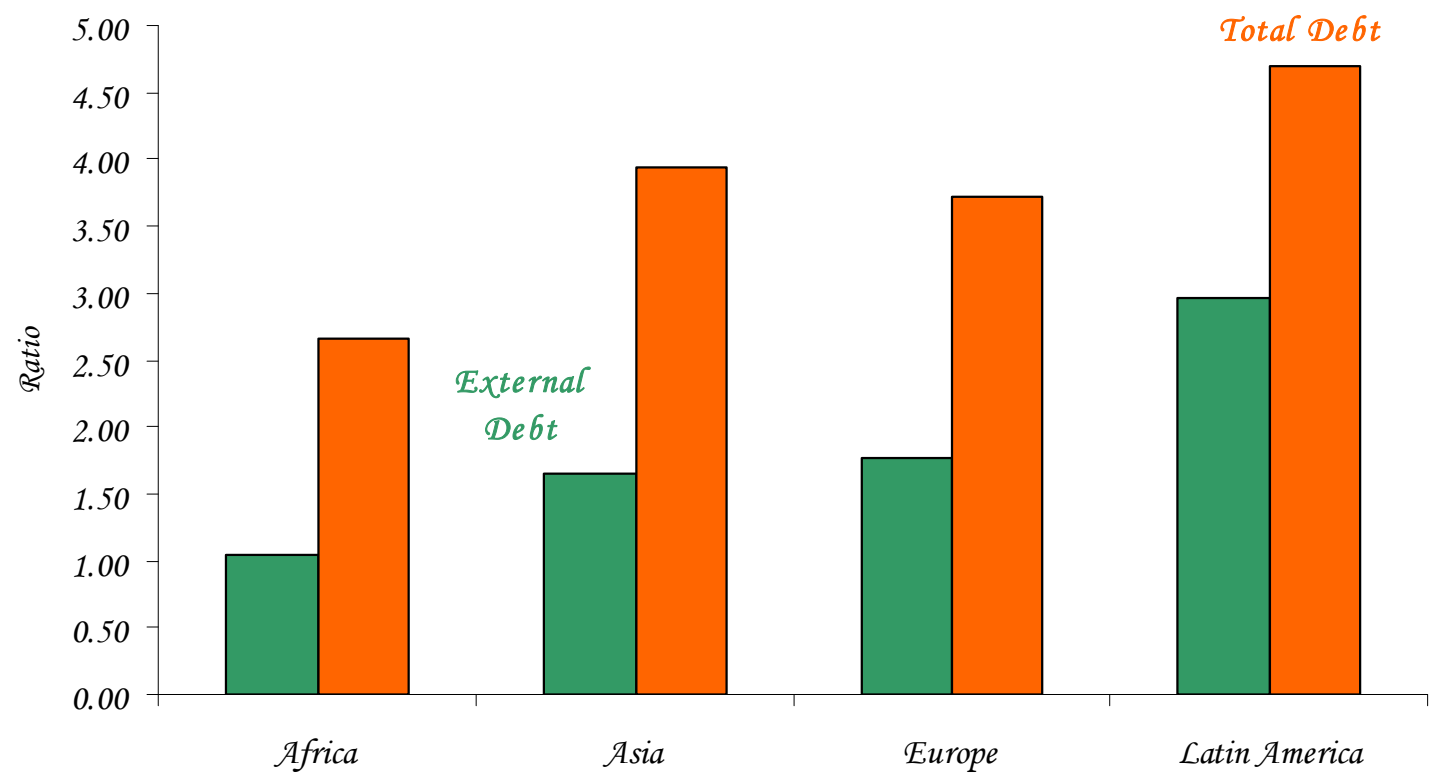

Figure 4 gives a different perspective on the data by providing the frequency distribution of external debt to GDP and total debt to GDP across all the external debt episodes in our sample for which we have full data. As the figure illustrates, external debt to government revenue ratios are massed at a much smaller average than total debt to government revenue ratios during the year of an external default, with a mean of 2.38 versus 4.21. This order-of-magnitude difference is consistent across individual episodes (as Table 2 above highlights for some well-known cases). It is also consistent across regions (Figure 4) and time. 
Obviously, if domestic debt were trivial, then the frequency distribution of the total debt ratio at the time of default should overlap that of domestic debt. This is hardly the case, and a standard battery of tests rejects this hypothesis across the board. ${ }^{12}$

Figure 4. Pu6lic De6t-to-Revenue Ratios During External Default

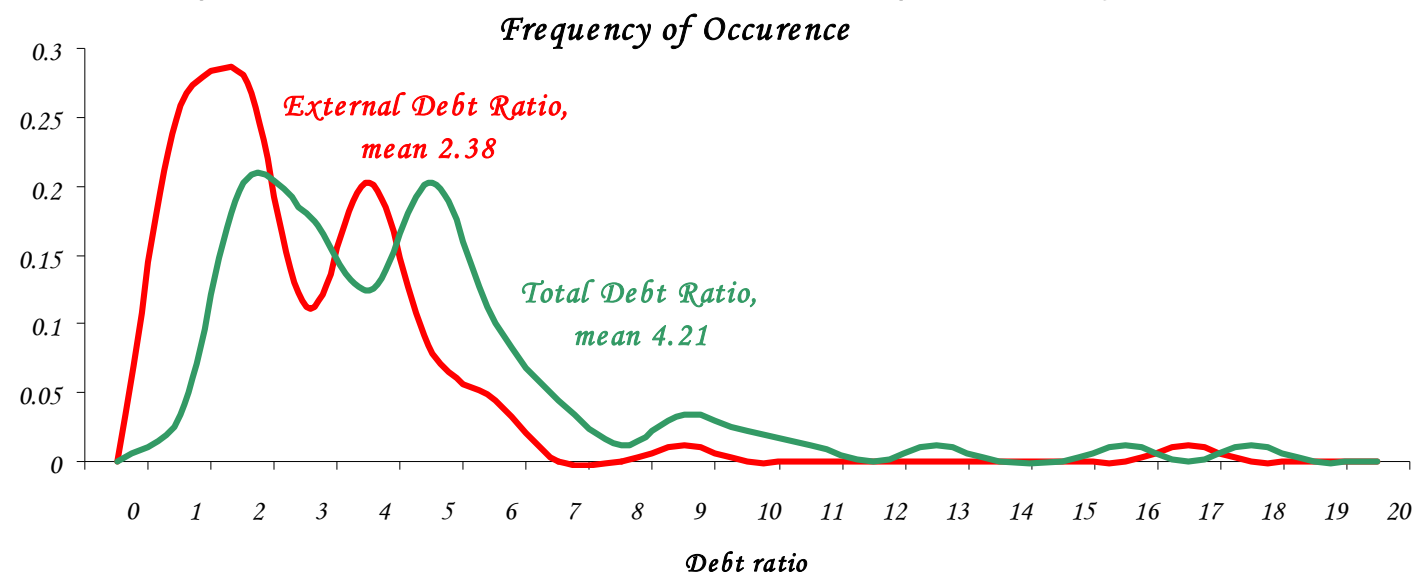

Finally, we note that domestic debt is not static around default episodes. In fact, domestic debt often shows the same frenzied increases in the run-up to external default as foreign borrowing does. The pattern is illustrated in Figure 5, which depicts debt accumulation during the five years up to and including external default across all the episodes in our sample.

Presumably, the comovement of domestic and foreign debt is produced by the same procyclical behavior of fiscal policy documented by previous researchers. ${ }^{13}$ As shown repeatedly over time, emerging market governments are prone to treating

\footnotetext{
${ }^{12}$ For example, the Kolmogorov-Smirnov test rejects the hypothesis that the two frequency distributions are equal at the $1 \%$ level.

${ }^{13}$ See Gavin and Perotti (1997) and Kaminsky, Reinhart, and Vegh (2004) for evidence on procyclical macroeconomic policies. See also Aguiar and Gopinath (2007) for a model in which the procyclical behavior of the current account can be rationalized by the high ratio of permanent to transitory shocks in emerging markets.
} 
favorable shocks as permanent, fueling a spree in government spending and borrowing that ends in tears. ${ }^{14}$ Figure 5 does not continue past the default date $T$. If it did, we would see that countries often continue to run up domestic public debt after they are shut off from international capital markets.

Figure 5. The Runup in Domestic and External Debt on the Eve of Default, Average Default Episode: 1800-2006

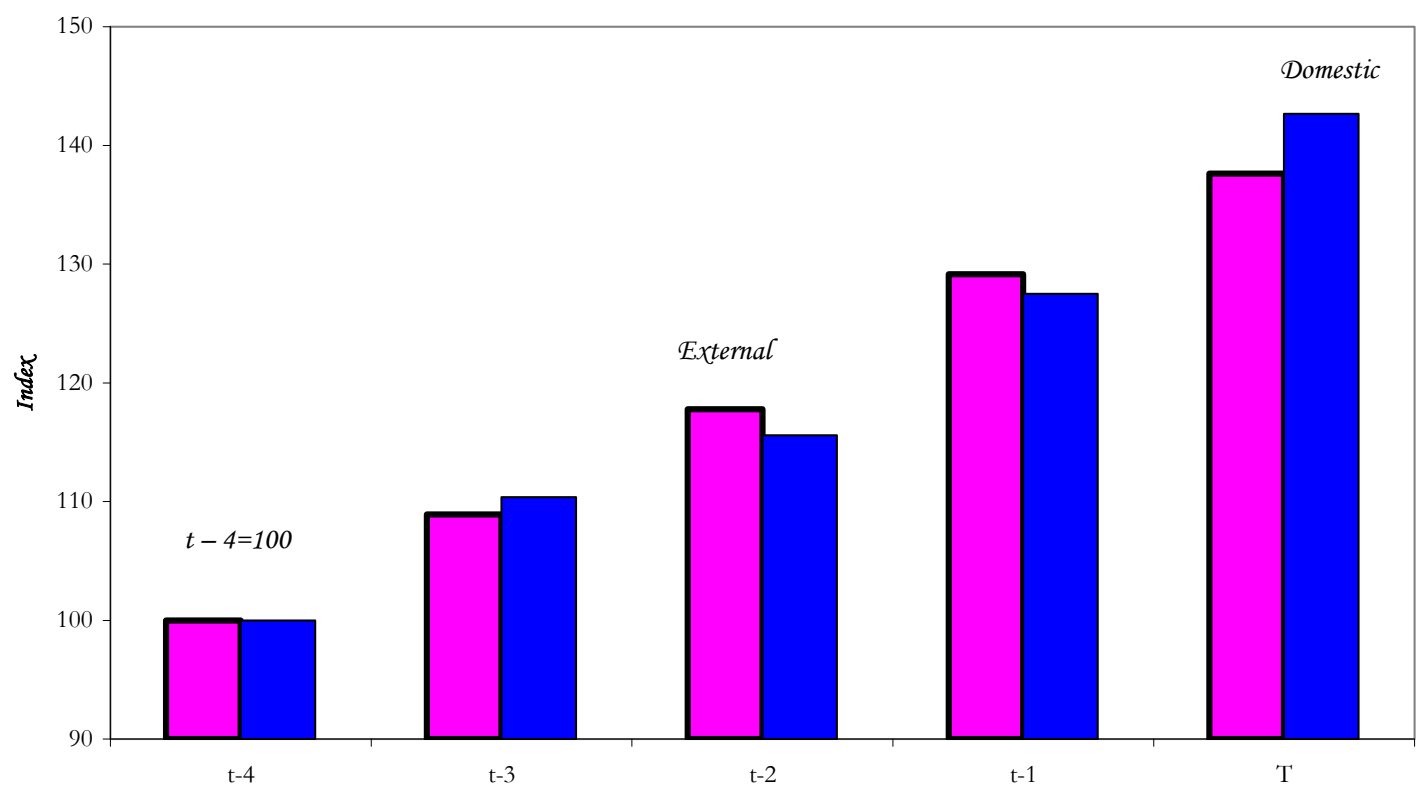

Sources: See Data Appendices I and II in Reinhart and Rogoff (2008).

Domestic debt often builds up in the aftermath of external defaults. The case of pre-communist China is a caricature of the typical post-default trajectory. China's government depended almost exclusively on external debt until two major defaults in 1921 and 1939, with public domestic debt exploding in the aftermath of both incidents. By the mid-1940s, China's government relied almost exclusively on domestic debt.

\footnotetext{
${ }^{14}$ Reinhart and Rogoff (2008) argue that there are strong parallels between today's emerging markets and the behavior of today's rich countries when they were at the same stage of development.
} 


\section{Domestic Debt in High-Inflation Episodes: Again a Missing Link?}

Another literature that has by and large ignored domestic debt is the empirical literature on high and hyperinflation. Ever since Cagan (1956), researchers have concentrated on the government's incentives to gain seignorage revenues off the monetary base. ${ }^{15}$ Indeed, a recurring paradox in this literature is why governments sometimes seem to inflate above and beyond the seignorage-maximizing rate. Many clever and plausible answers have been offered to this question, with issues of time consistency and credibility featuring prominently. We submit, however, that the presence of significant domestic public debt may be a major overlooked factor, especially considering — as we have already discussed — that a large share of debt was often long term and non-indexed. We do not refer simply to the study of rare hyperinflation episodes but equally to the much more common phenomenon of high and moderately high inflation as studied, for example, by Dornbusch and Fischer (1986) and many others since.

Although there are literally hundreds of empirical papers on inflationary finance in developing countries and post-conflict economies, domestic debt is rarely mentioned, much less employed in time-series analysis. As in the external debt literature, the implicit assumption is that domestic public debt is relatively unimportant. But is this a good approximation? Perhaps the answer is yes in some cases, but as Table 3 suggests, there are many important episodes where domestic debt appears to have been a major

\footnotetext{
${ }^{15}$ Sargent (1982) does include data on central bank holdings of treasury bills for the five post-World War I countries (Austria, Germany, Poland, Hungary, Czechoslovakia) in his classic paper. But of course, these debts are essentially a wash on the consolidated government balance sheet.
} 
factor in the government's incentive to inflate, if not indeed the dominant one. ${ }^{16}$ Thus a comparison of actual inflation rates to any hypothetical "seignorage-maximizing rate," calculated only off the monetary base, may often be beside the point.

We see in Table 3, for example, that when post-World War I inflation first spiked up to 66 percent in Germany in 1920, domestic debt was almost triple the size of the monetary base. In the case of Brazil, debt was almost 20 times the size of the money base. $^{17}$

The importance of domestic debt is hardly confined to hyperinflations. Table 3 lists a number of high-inflation episodes as well. Domestic public debt was almost 80 percent of total domestic liabilities (including currency) in 1945 Japan, when inflation went over 500 percent. In all of the cases listed in Table 3, domestic public debt is at least the same order of magnitude as the monetary base (with the exception of Norway in 1918, where it was slightly below).

Precise calculations of how much governments gained by inflating down the real value of debt require considerably more information on the maturity structure and interest payments than is available in our cross-country data set. One also needs to understand bank reserve requirements, interest rate regulations, the degree of financial repression, and other constraints to make any kind of precise calculation. But the fact that domestic nominal debt is so large compared to base money across so many important high-

\footnotetext{
${ }^{16}$ Of course, the possibility of using unanticipated inflation to default on nominal debt is well understood in the theoretical literature, e.g., Barro (1983).

${ }^{17}$ The Brazil case is exceptional in that some of the debt was indexed to inflation, although lags in the indexation scheme still made it possible for the government to largely inflate away the debt with a high enough rate of inflation. Indeed, this appears to be exactly what happened as the country lurched in and out of hyperinflation for many years.
} 
inflation episodes suggests that this factor needs to be given far more attention in future studies. $^{18}$

\section{VI: Who Is Senior? Domestic Residents or Foreigners?}

We have shown that domestic debt is large in general, and in many episodes of external default or high inflation, in particular. Clearly, in trying to understand how crises play out, it would be helpful to better understand the relative seniority of domestic and foreign debt. This section is an attempt to provide a first pass at some key characteristics of the data. Clearly, the answer is going to differ across countries and time. Many factors, such as central bank independence and exchange rate regime, are likely going to be relevant. Nevertheless, a few simple comparisons of the trajectory of output and inflation during the run-up and aftermath to domestic and external defaults are revealing. $^{19}$

Our calculations can be taken only as suggestive for several reasons. One is simply that, as we have already emphasized, there is no comprehensive database on overt domestic debt defaults prior to our own, much less on de facto defaults. While we are confident that we have a relatively complete picture of external defaults and episodes of high inflation in our sample, we simply do not know how many domestic default episodes we may have missed, even restricting attention to de jure defaults. Appendix I provides a broad indication of how hidden in the historical archives are clear episodes of

\footnotetext{
${ }^{18}$ Calvo and Guidotti (1992) develop a model of the optimal maturity structure of nominal debt, where the government trades off flexibility (the option to inflate away long-term debt when under financial duress) versus maintaining high credibility for maintaining a low inflation rate (achieved by having very short-term debt which is more difficult to inflate away).

${ }^{19}$ It should also be noted that other economic indicators (besides inflation and per capita GDP growth, which we examine in detail) would provide a richer answer to the broad question of how bad conditions have to be before contemplating default (specifically, the impacts of domestic versus foreign default on social indicators relating to poverty, health, income distribution, etc., are bound to be quite different).
} 
domestic default or restructuring. Thus, our list of domestic defaults is surely a lower bound on the actual incidence.

Table 3. Inflation and Domestic Debt: Selected Episodes, 1917-1994

\begin{tabular}{|c|c|c|c|c|c|}
\hline Country & Year & Inflation & $\begin{array}{l}\text { Domestic } \\
\text { debt/GDP }\end{array}$ & $\begin{array}{l}\text { Base } \\
\text { Money/GDP }\end{array}$ & $\begin{array}{l}\text { Domestic } \\
\text { debt/ Total } \\
\text { domestic } \\
\text { liabilities } \\
\end{array}$ \\
\hline \multicolumn{6}{|c|}{ Some Hyperinflations } \\
\hline Argentina & 1989 & 3079.5 & 25.6 & 16.4 & 61.2 \\
\hline \multirow[t]{2}{*}{ Brazil } & 1987 & 228.3 & 164.9 & 9.8 & 94.4 \\
\hline & 1990 & 2947.7 & 155.1 & 7.1 & 95.6 \\
\hline \multirow[t]{3}{*}{ Germany } & 1920 & 66.5 & 52.6 & 19.4 & 73.0 \\
\hline & 1923 & 22220194522.37 & 0.0 & 0.0 & 1.0 \\
\hline & & High Infla & ions & & \\
\hline \multirow[t]{2}{*}{ Greece } & 1922 & 54.2 & 53.0 & 34.3 & 60.7 \\
\hline & 1923 & 72.6 & 41.3 & 32.7 & 55.9 \\
\hline \multirow[t]{2}{*}{ Italy } & 1917 & 43.8 & 79.1 & 24.1 & 76.6 \\
\hline & 1920 & 56.2 & 78.6 & 23.5 & 77.1 \\
\hline \multirow{2}{*}{ Japan } & 1944 & 26.6 & 236.7 & 27.8 & 89.5 \\
\hline & 1945 & 568.1 & 266.5 & 74.4 & 78.2 \\
\hline \multirow[t]{2}{*}{ Norway } & 1918 & 32.5 & 79.3 & 86.4 & 47.9 \\
\hline & 1920 & 18.1 & 106.9 & 65.6 & 62.3 \\
\hline \multirow[t]{2}{*}{ Philippines } & 1981 & 13.1 & 10.4 & 6.6 & 61.1 \\
\hline & 1984 & 46.2 & 11.0 & 13.9 & 44.2 \\
\hline \multirow[t]{2}{*}{ Turkey } & 1990 & 60.3 & 14.7 & 7.4 & 66.6 \\
\hline & 1994 & 106.3 & 20.2 & 7.1 & 73.9 \\
\hline
\end{tabular}

Sources: See Reinhart and Rogoff (2008, Appendix I). Money and Debt stock refer to levels at the beginning of each episode.

Finally, but worthy of discussion, our approach is systematic in documenting the incidence of default but it is silent on assessing the magnitude of default. Even though our new database on public debt can provide a valuable insight on the magnitudes involved in the original default or restructuring, it would be a stretch of the imagination to suggest that these data provide a snapshot of the subsequent restructuring nuances or the actual recovery rates. With these caveats in mind, a number of results stand out. 


\section{The antecedents of domestic and external default}

First, how bad are macroeconomic conditions on the eve of default?

Unambiguously, output declines in the run-up to default on domestic debt are typically significantly worse than for external debt. As highlighted in Figure 6 and 7, the average cumulative decline in output during the three-year run-up to a domestic default crisis is 8 percent. The output decline on the year of the domestic debt crisis alone is 4 percent; the comparable average decline for the external debt events is 1.2 percent. To compare the antecedents of the domestic and external defaults, we performed a variety of tests for individual years, as well as for the cumulative change in the window prior to default. In the latter test, there are a total of 224 observations for domestic crises (that is, the number of annual observations in advance of domestic crises) and 813 for external crashes (again, years times number of crises).

As noted earlier, the results have to be interpreted with care, as many domestic episodes are twin default crises and, as such, output is also suffering from limited access (if at all) to external credit. 
Figure 6. Domestic and external crises

Level of real GDP, index $t-4=100$

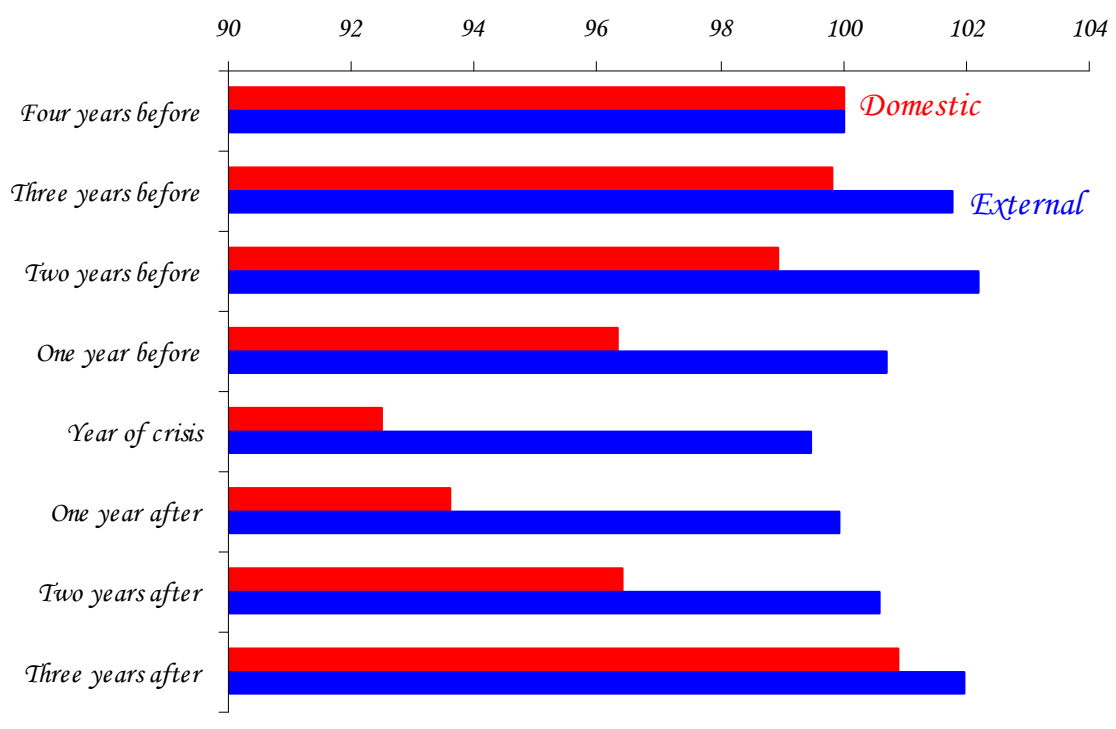

Figure 7. Real GDP: Domestic and external crises Cumulative frequency of occurrence, percent

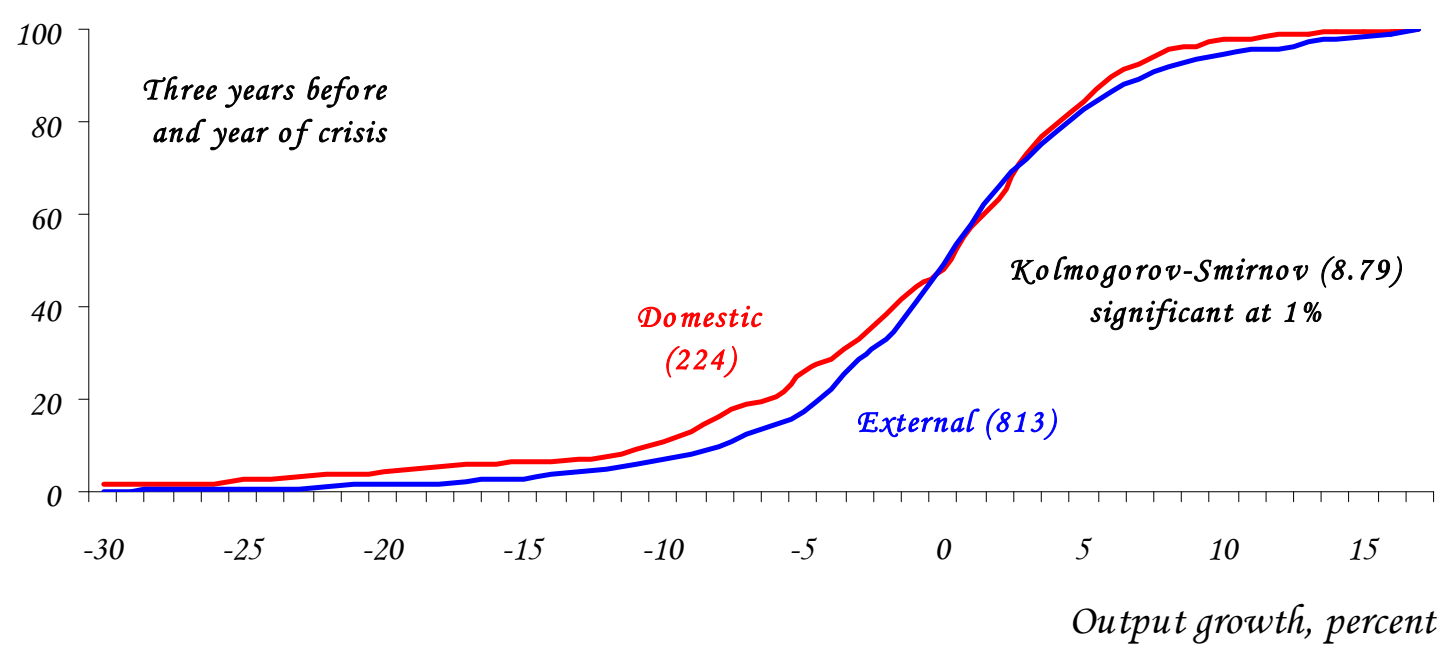

The comparable exercise for the inflation rate yields even starker differences (Figures 8 and 9); default through inflation goes hand in hand with domestic defaultbefore, during, and after the more explicit domestic expropriations. The extensive 
scholarly literature on inflation has been silent on this point. ${ }^{20}$ Inflation during the year of external default is on average high, at 33 percent. $^{21}$ However, inflation truly gallops during domestic debt crises, averaging 170 percent in the year of the default. ${ }^{22}$ After the domestic default, inflation remains at or above 100 percent in the following years. We conclude that overt domestic default tends to occur only in times of severe macroeconomic distress.

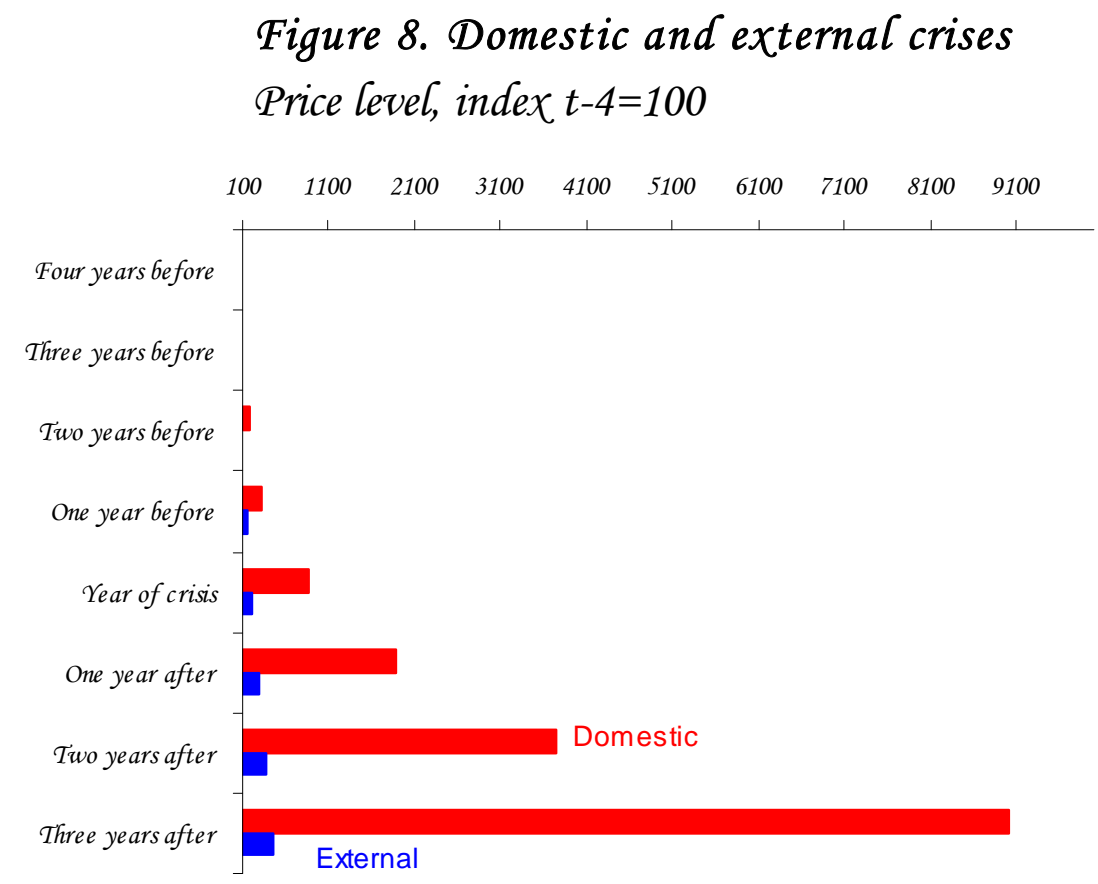

\footnotetext{
${ }^{20}$ Reinhart and Savastano (2003) do discuss the forcible conversion of foreign currency bank deposits (as in Argentina in 2002) during the hyperinflations in Bolivia and Peru (the dates of these episodes are listed in Appendix III.

${ }^{21}$ See the IMF's World Economic Outlook.

${ }^{22}$ We have excluded Bolivia's 1982 domestic default from these averages, as inflation peaks at over 11,000 percent on the year before $(t-1)$ the domestic default.
} 
Figure 9. Domestic and external crises

Cumulative frequency of occurrence, percent

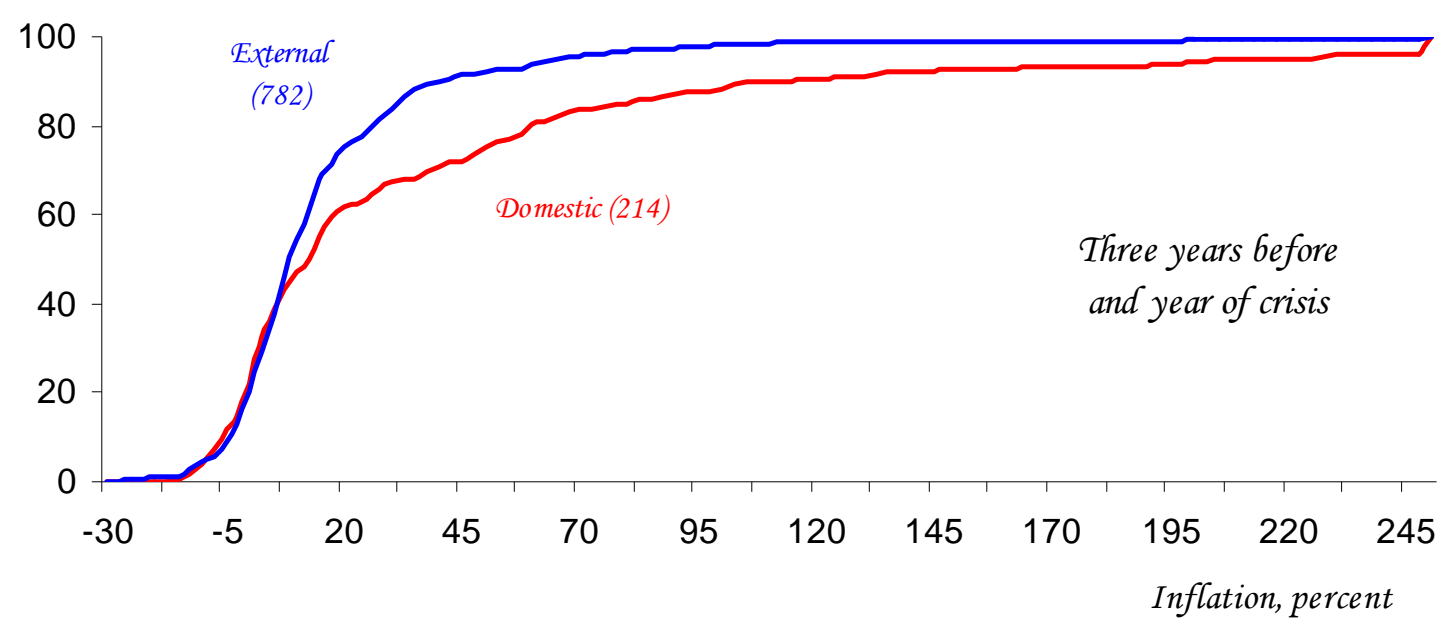

\section{The incidence of domestic and external default}

To shed some light on the incidence of expropriation of residents versus nonresidents, we constructed four time series for the period 1800-2007: the probability of external default (or the share of countries in our sample that are in external default in a given year); the comparable statistic for domestic default episodes; the probability of an inflation crisis (defined here as the share of countries in any given year during our more than 200-year sample where the annual rate of inflation exceeded 20 percent); and the sum of the incidence of high inflation and domestic default, which summarizes the expropriation of the holdings of domestic residents. ${ }^{23,24}$

Figure 10 shows the probability of external default versus the comparable statistic for domestic default either through inflation or explicit default. For the early period

\footnotetext{
${ }^{23}$ Details on the underlying macroeconomic data are given in Reinhart and Rogoff (2008).

${ }^{24}$ The United States is, of course, the modern exception. Virtually all U.S. debt is domestic (as the Carter bonds have been extinguished), yet about 40 percent is held by nonresidents (mostly central banks and other official institutions), but it is dollar denominated. Thus, inflation in the United States would also affect nonresidents.
} 
through World War II, the incidence of external default is higher. ${ }^{25}$ Table $^{2}$ presents $^{2}$ some summary statistics on the underlying data. For 1800-1939, the probability of external default is about 20 percent versus 12 percent for domestic residents. For the entire sample, there is no statistically significant difference in the incidence of default on locals versus foreigners. With the widespread adoption of fiat money, inflation apparently became the more expedient form of expropriation. As a result, the incidence of taxing locals increased after World War II. ${ }^{26}$

Figure 11 plots the probability of domestic default as a share of the probability of default. A ratio above 0.5 implies domestics do worse, while one less than 0.5 implies foreigners do worse.

Certainly, this admittedly very crude first pass at the evidence does nothing to dissuade our prior belief that domestic debt is often held by important political stakeholders in debtor countries, and cannot always be lightly dismissed as strictly junior debt.

\footnotetext{
${ }^{25}$ The huge spike in external defaults in the 1820s owes to the much-studied first wave of sovereign defaults of the newly independent Latin American countries_-but Greece and Portugal also defaulted at this time.

${ }^{26}$ See the memorandum item in Table 5.
} 


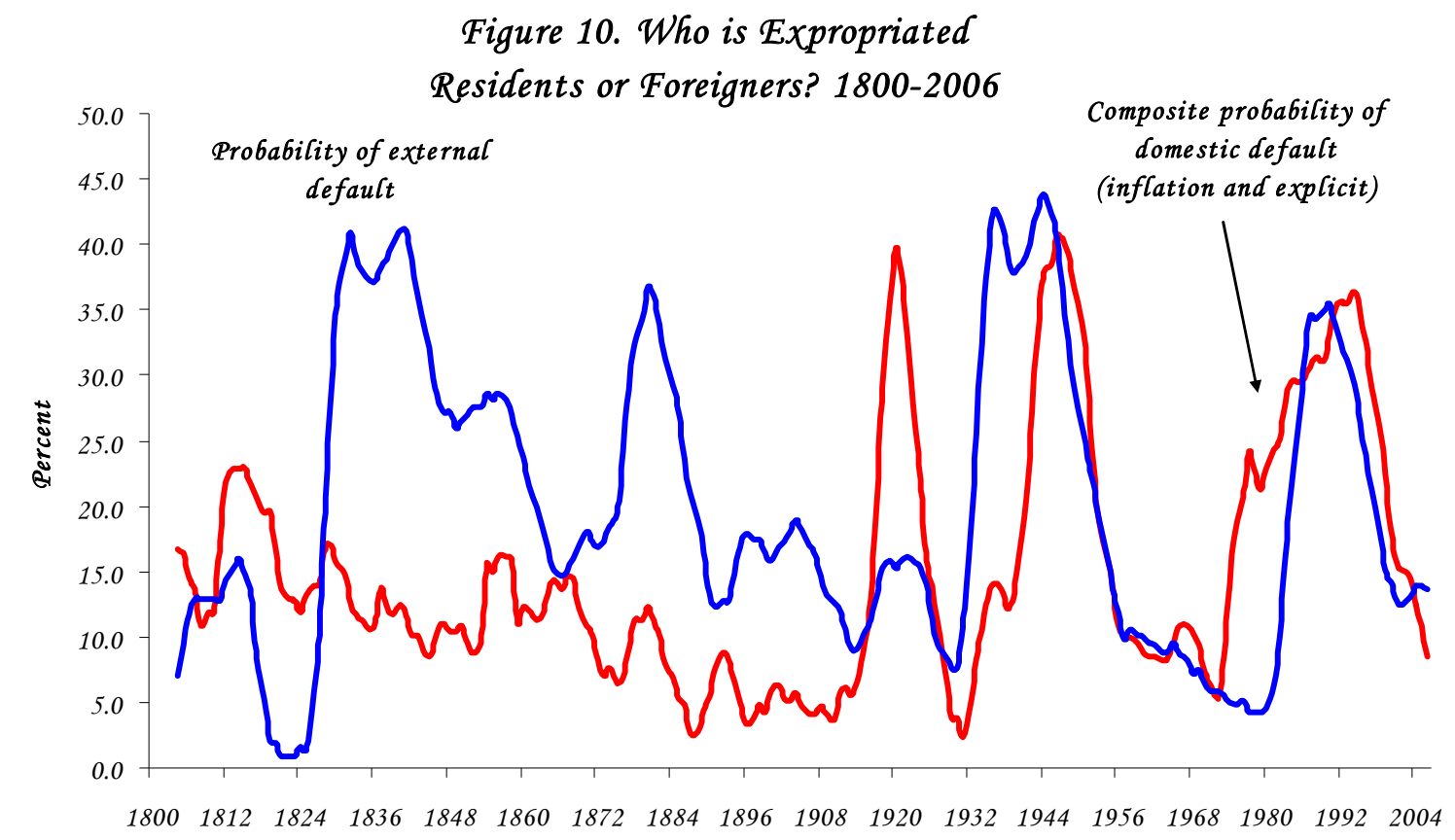

Figure 11. Composite Pro6ability of Domestic Default as a Share of Total Default Pro6a6ility 1800-2006

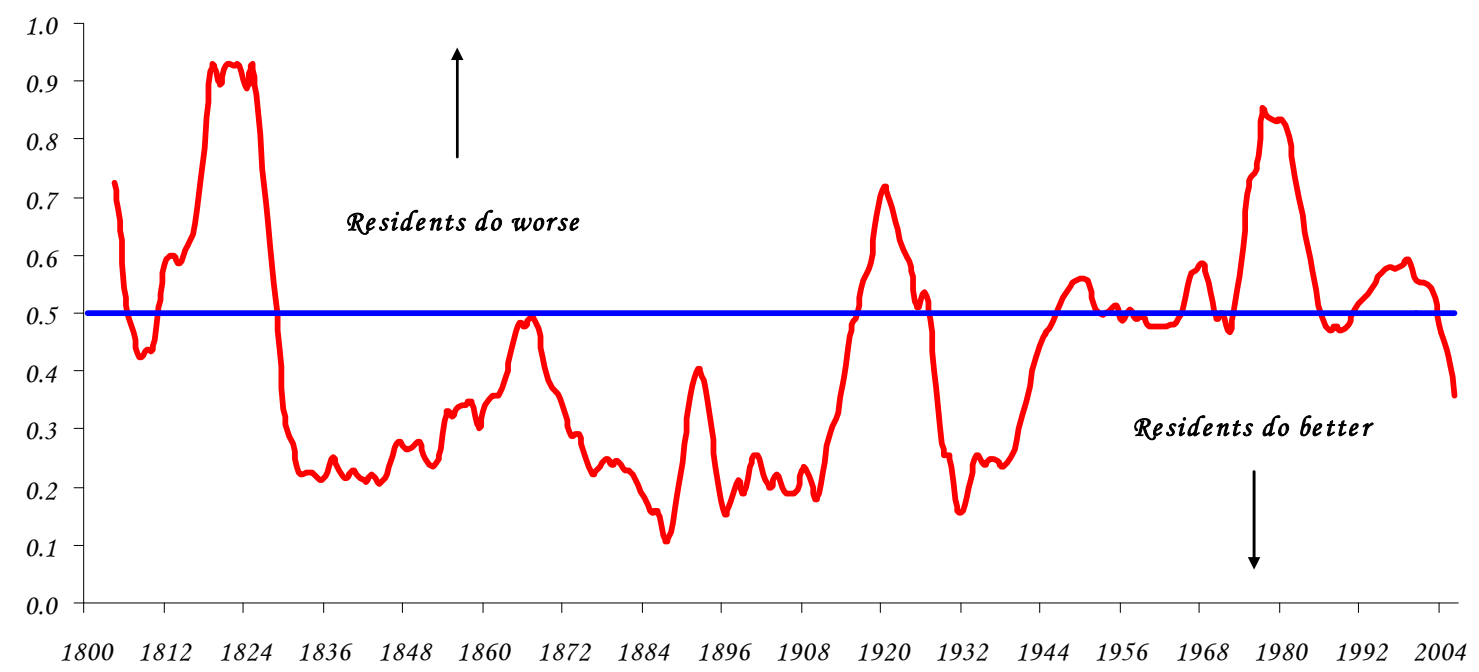

\section{Conclusions}

In this paper, we provide an extensive new cross-country data set on a key macroeconomic variable that governments often manage to keep remarkably hidden from 
view: domestic public debt. We also present what we believe to be the first attempt at a cross-country international catalogue of historical defaults on domestic public debt, spanning two centuries and sixty-four countries.

Our first look at the data suggests that researchers need to revisit the empirical literature on the sustainability of external government debt and on government's incentives to engage in high and hyperinflation, taking into account the newly uncovered data on domestic public debt. Of course, how the overhang of domestic debt impacts inflation and external default will vary across episodes and circumstances. In some cases, the domestic debt is eliminated through high inflation, in other cases, governments default on external debt.

How did domestic public debt in emerging markets fall off many economists' radar screen? Many researchers, aware only of difficulties that emerging markets had in issuing debt in the ultra-high-inflation 1980s and 1990s, simply believed that no one would ever voluntarily lend money to a kleptocratic emerging market government. The logical implication was that such debt must not exist. True, there are exceptions. Alesina and Tabellini (1990) consider a theoretical case where domestic debt is honored ahead of external debt. But absent any data, or even any awareness of the one-time existence of significant quantities of domestic public debt in virtually every emerging market, these isolated examples have had no great impact on the mainstream academic or policy literature.

Perhaps the most surprising and significant finding of our study is simply the lack of transparency so many governments and multilateral institutions exhibit in making time series on domestic debt easily available. After all, these governments routinely tap 
domestic and foreign markets to sell debt. Standard auction theory—much of which is admittedly static — suggests that it should be in the interest of sellers to convey information, especially when the debt can be resold in secondary markets. Even more puzzling is why global investors do not insist on historical information relevant to the value of securities they may purchase. Understanding why so many governments do not make it easier for standard databases to incorporate their debt history is an important question for future research.

From a policy perspective, there is a plausible case that an international agency would be providing a valuable public good if it could enforce (or at least promote) basic reporting requirements and transparency across countries. Given the apparent large historical role of domestic public debt in helping to precipitate developing country external debt and inflation crises, it is a great curiosity indeed that today's multilateral financial institutions have never fully taken up the task of systematically publishing the data. This failure, especially in light of these agencies' supposed role at the vanguard of warning policymakers and investors about crisis risks, is stunning. Instead, the system has seemed to forget about the history of domestic debt entirely, thinking that today's blossoming of internal public debt markets is something entirely new and different. ${ }^{27}$ But as our historical data set on domestic debt underscores with surprising force, nothing could be further from the truth.

\footnotetext{
${ }^{27}$ Beyond simply reporting debt data, international financial institutions such as the International Monetary Fund or the World Bank can, of course, also help with disseminating best practices (see, for example, the institutional evolution discussed in Wallis and Weingast, 1988).
} 


\section{References}

Aguiar, Mark, and Gita Gopinah (2007). "Emerging Market Business Cycles: The Cycle Is the Trend,” Journal of Political Economy, 115 (1), February, 69-102.

Alesina, Alberto, and Guido Tabellini (1990). "A Positive Theory of Fiscal Deficits and Government Debt”, The Review of Economic Studies, 57, 403-414.

Arellano, Cristina, and Narayana Kocherlakota (2008). "Internal Debt Crises and Sovereign Defaults,” NBER Working Paper No. 13794 February, 2008.

Barro, Robert (1983). “Inflationary Finance under Discretion and Rules,” Canadian Journal of Economics, 16 (1), February, 1-16.

Bazant, Jan (1968). Historia de la Deuda Exterior de Mexico: 1823-1946, (Mexico: El Colegio de Mexico).

Beers and Chambers, (2007). Sovereign Defaults At 26-Year Low, To Show Little Change In 20, Standard and Poor's.

Bordo, Michael, and Barry Eichengreen (1999). "Is Our Current International Economic Environment Unusually Crisis Prone?" Prepared for the Reserve Bank of Australia Conference on Private Capital. Sydney, August.

Bordo, Michael, Barry Eichengreen, Daniela Klingebiel, and Maria Soledad MartinezPeria (2001). “Is the Crisis Problem Growing More Severe?” Economic Policy, 16, April, 51-82.

Brock, Philip (1989). "Reserve Requirements and the Inflation Tax,” Journal of Money, Credit and Banking, 21 (1), February, 106-121.

Bulow, Jeremy, and Kenneth Rogoff (1989). “A Constant Recontracting Model of Sovereign Debt,” Journal of Political Economy, 97 (1), February, 155-178.

Cagan, Philip (1956). “The Money Dynamics of Hyperinflation.” In Milton Friedman (ed.), Studies in the Quantity Theory of Money. Chicago: University of Chicago Press.

Calvo, Guillermo, and Pablo Guidotti (1992). "Optimal Maturity of Nominal Government Debt: An Infinite Horizon Model,” International Economic Review 33 (November), 895-919.

Calvo, Guillermo (1989). "Is Inflation Effective for Liquidating Short-Term Nominal Debt? IMF Working Paper WP/89/2, January. 
Calvo, Guillermo (1991), “The Perils of Sterilization,” IMF Staff Papers, 38 (4), December, 921-926.

Carreras, Albert and Xavier Tafunell, eds. (2005). Estadísticas Históricas de España, Siglos XIX-XX, (Bilbao: Fundación BBVA).

Correlates of War http://correlatesofwar.org/

Cowan, Kevin, Eduardo Levy-Yeyati, Ugo Panizza, and Federico Sturzenegger (2006). "Sovereign Debt in the Americas: New Data and Stylized Facts," Inter-American Development Bank, Research Department, Working Paper \#577.

Diamond, Peter A. (1965). "National Debt in a Neoclassical Growth Model," The American Economic Review, 55 (5), December, 1126-1150.

Dornbusch, Rudiger, and Stanley Fischer (1993). "Moderate Inflation.” World Bank Economic Review, 7 (1), 1-44.

Eaton, Jonathan, and Mark Gersovitz (1981). "Debt with Potential Repudiation: Theory and Estimation,” Review of Economic Studies 48 (2), April, 289-309

Eichengreen, Barry (1991). "Historical Research on International Lending and Debt," Journal of Economic Perspectives 5 (2), Spring, 149-169.

Eichengreen, Barry, and Ricardo Hausman (1999). "Exchange Rates and Financial Fragility" National Bureau of Economic Research Working Paper 7418, November.

Fischer, Stanley, Ratna Sahay and Carlos Végh (2002). "Modern Hyper- and High Inflations,” Journal of Economic Literature, 40 (3), September, 837-880.

Flandreau, Marc, and Frederic Zumer (2004). The Making of Global Finance, 18801913 (Paris: OECD).

Frankel, S. Herbert (1938). Capital Investment in Africa, Its Course and Effects, (London: Oxford University Press).

Gavin, Michael, and Roberto Perotti (1997). "Fiscal Policy in Latin America," NBER Macroeconomics Annual, 12, 11-61.

Jeanne, Olivier and Alexandra Guscina (2006). "Government Debt in Emerging Market Countries: A New Data Set." IMF Working Paper No. 6/98, April.

Kaminsky, Graciela, Carmen M. Reinhart, and Carlos A.Végh (2004). "When It Rains, It Pours: Procyclical Capital Flows and Policies," NBER Macroeconomics Annual, 19, 1153. 
Kotlikoff, Lawrence J, Torsten Persson, and Lars E. O. Svensson (1988). “Social Contracts as Assets: A Possible Solution to the Time-Consistency Problem,” The American Economic Review, 78, 662-677.

League of Nations (various issues). Statistical Yearbook: 1926-1944. (Geneva: League of Nations).

Lindert, Peter H., and Peter J. Morton (1989). “How Sovereign Debt Has Worked,” in Jeffrey Sachs, ed., Developing Country Debt and Economic Performance, Vol. 1 (University of Chicago Press), 39-106.

Maddison, Angus (2004). Historical Statistics for the World Economy: 1-2003 AD (Paris: OECD) http://www.ggdc.net/maddison/

Marichal, Carlos, (1989). A Century of Debt Crises in Latin America: From Independence to the Great Depression, 1820-1930 (Princeton: Princeton University Press).

Mitchell, Brian R. (2003). International Historical Statistics: Africa, Asia, and Oceania, 1750-2000 (London: Palgrave MacMillan).

Mitchell, Brian R. (2003). International Historical Statistics: The Americas, 1750-2000 (London: Palgrave MacMillan).

Persson, Torsten, Gérard Roland, and Guido Tabellini (2000). "Comparative Politics and Public Finance,” Journal of Political Economy 108, 1121-1141.

Prasad, Eswar, Kenneth Rogoff, Shang-Jin Wei and M. Ayhan Kose (2003). "Effects of Financial Globalization on Developing Countries: Some Empirical Evidence,” IMF Occasional Paper No. 220.

Reinhart, Carmen M., and Kenneth Rogoff (2008). "This Time is Different: A Panoramic View of Eight Centuries of Financial Crises.” NBER Working Paper 13882, March.

Reinhart, Carmen M., Kenneth S. Rogoff, and Miguel A. Savastano (2003). "Debt Intolerance,” Brookings Papers on Economic Activity, Spring, 1-74.

Reinhart, Carmen M., and Miguel A. Savastano (2003). "The Realities of Modern Hyperinflation,” (with Miguel A. Savastano), Finance and Development, June, 20-23.

Sargent, Thomas J. (1982). “The Ends of Four Big Hyperinflations,” in Robert J. Hall, ed, Inflation: Causes and Effects. Chicago: University of Chicago Press. 
Sturzenegger, Federico, and Jeromin Zettelmeyer (2006). Debt Defaults and Lessons from a Decade of Crises. Cambridge: MIT Press, December.

Tomz, Michael (2007). Reputation and International Cooperation, Sovereign Debt Across Three Centuries. Princeton: Princeton University Press.

United Nations, Department of Economic Affairs (1948). Public Debt, 1914-1946 (New York: United Nations).

United Nations, Department of Economic Affairs (various years). Yearbook, 1948-1984 (New York: United Nations).

Wallis, John, and Barry R. Weingast (1988). "Dysfunctional or Optimal Institutions: State Debt Limitations, the Structure of State and Local Governments, and the Finance of American Infrastructure," in Garret, Grady, and Jackson, ed. Fiscal Challenges: An Interdisciplinary Approach to Budget Policy. Cambridge University Press, 331-363.

Winkler, Max (1933). Foreign Bonds: An Autopsy (Philadelphia: Roland Sway Co.).

Woodford, Michael (1995). "Price-level Determinacy Without Control of a Monetary Aggregate,” Carnegie-Rochester Conference Series on Public Policy 43, 1-46.

Wynne, William H (1951). State Insolvency and Foreign Bondholders: Selected Case Histories of Governmental Foreign Bond Defaults and Debt Readjustments, Vol. II (London: Oxford University Press). 


\section{Appendix I. The sample}

The debt data covers the countries shown in Appendix Table 1 (9 in Africa; 9 in Asia; 23 in Europe; 19 in Latin America, 2 in North America; and 2 in Oceania). The domestic default episodes encompass all countries that have defaulted on their domestic debt (See Appendix Table 2 for a definition of default and Appendix Table 3 for a full list of the episodes).

As the final column in Appendix Table 1 illustrates, our sample of sixty-four countries indeed accounts for about 90 percent of world GDP. Many of these countries, particularly those in Africa and Asia, have become independent nations only relatively recently (column 2). 


\begin{tabular}{|c|c|c|c|}
\hline \multicolumn{4}{|c|}{ Appendix Table 1. Countries, Regions, and World GDP } \\
\hline \multirow{2}{*}{$\begin{array}{l}\text { Country (An asterisk } \\
\text { denotes no sovereign } \\
\text { default or rescheduling } \\
\text { history) }\end{array}$} & \multirow[t]{2}{*}{ Year of Independence } & \multicolumn{2}{|c|}{$\begin{array}{c}\text { Share of World Real GDP } \\
1990 \text { International Geary-Khamis US dollars }\end{array}$} \\
\hline & & 1913 & 1990 \\
\hline \multicolumn{4}{|l|}{ Africa } \\
\hline Cote D'Ivoire & 1960 & 0.00 & 0.06 \\
\hline Egypt & 1831 & 0.40 & 0.53 \\
\hline Ghana & 1957 & 0.06 & 0.06 \\
\hline Kenya & 1963 & 0.00 & 0.10 \\
\hline Mauritius * & 1968 & 0.00 & 0.03 \\
\hline Morocco & 1956 & 0.13 & 0.24 \\
\hline South Africa & 1910 & 0.36 & 0.54 \\
\hline Tunisia $^{\mathrm{a}}$ & 1881-1957 & 0.06 & 0.10 \\
\hline Zimbabwe & 1965 & 0.00 & 0.05 \\
\hline \multicolumn{4}{|l|}{ Asia } \\
\hline China & 1368 & 8.80 & 7.70 \\
\hline India & 1947 & 7.47 & 4.05 \\
\hline Indonesia & 1949 & 1.65 & 1.66 \\
\hline Japan & 1590 & 2.62 & 8.57 \\
\hline Korea * & 1945 & 0.34 & 1.38 \\
\hline Malaysia * & 1957 & 0.10 & 0.33 \\
\hline Philippines & 1947 & 0.34 & 0.53 \\
\hline Singapore * & 1965 & 0.02 & 0.16 \\
\hline Thailand * & 1769 & 0.27 & 0.94 \\
\hline \multicolumn{4}{|l|}{ Europe } \\
\hline Austria & 1282 & 0.86 & 0.48 \\
\hline Belgium * & 1830 & 1.18 & 0.63 \\
\hline Bulgaria & 1878 & 0.26 & 0.18 \\
\hline Czechoslovakia & 1918 & 0.00 & 0.49 \\
\hline Denmark * & 980 & 0.43 & 0.35 \\
\hline Finland * & 1917 & 0.23 & 0.31 \\
\hline France & 943 & 5.29 & 3.79 \\
\hline Germany & 1618 & 8.68 & 4.67 \\
\hline Greece & 1829 & 0.32 & 0.37 \\
\hline Hungary & 1918 & 0.60 & 0.25 \\
\hline Ireland & 1922 & 0.44 & 0.15 \\
\hline Italy & 1569 & 3.49 & 3.42 \\
\hline Netherlands * & 1581 & 0.91 & 0.95 \\
\hline Norway * & 1905 & 0.22 & 0.29 \\
\hline Poland & 1918 & 1.70 & 0.72 \\
\hline Portugal & 1139 & 0.27 & 0.40 \\
\hline Romania & 1878 & 0.80 & 0.30 \\
\hline Russia & 1457 & 8.50 & 4.25 \\
\hline Spain & 1476 & 1.52 & 1.75 \\
\hline Sweden $*$ & 1523 & 0.64 & 0.56 \\
\hline Switzerland & 1291 & 0.60 & 0.54 \\
\hline Turkey & 1453 & 0.67 & 1.13 \\
\hline United Kingdom * & 1066 & 8.22 & 3.49 \\
\hline
\end{tabular}

Sources: Correlates of War (2007), Maddison (2004).

Notes: An asterisk denotes no sovereign external default or rescheduling history; we do not include intergovernmental war loans such as the US loans to Great Britain during World War I.

aTunisia was a protectorate of France from 1881 to 1956. 


\begin{tabular}{|c|c|c|c|}
\hline \multicolumn{4}{|c|}{ Appendix Table 1 (concluded). Countries, Regions, and World GDP } \\
\hline & Year of Independence & \multicolumn{2}{|c|}{$\begin{array}{l}\text { Share of World Real GDP } \\
1990 \text { International } \\
\text { Geary-Khamis US dollars }\end{array}$} \\
\hline \multicolumn{4}{|l|}{ Latin America } \\
\hline Argentina & 1816 & 1.06 & 0.78 \\
\hline Bolivia & 1825 & 0.00 & 0.05 \\
\hline Brazil & 1822 & 0.70 & 2.74 \\
\hline Chile & 1818 & 0.38 & 0.31 \\
\hline Colombia & 1819 & 0.23 & 0.59 \\
\hline Costa Rica & 1821 & 0.00 & 0.05 \\
\hline Dominican Republic & 1845 & 0.00 & 0.06 \\
\hline Ecuador & 1830 & 0.00 & 0.15 \\
\hline El Salvador & 1821 & 0.00 & 0.04 \\
\hline Guatemala & 1821 & 0.00 & 0.11 \\
\hline Haiti & 1804 & 0.00 & 0.02 \\
\hline Honduras & 1821 & 0.00 & 0.03 \\
\hline Mexico & 1821 & 0.95 & 1.91 \\
\hline Nicaragua & 1821 & 0.00 & 0.02 \\
\hline Panama & 1903 & 0.00 & 0.04 \\
\hline Paraguay & 1811 & 0.00 & 0.05 \\
\hline Peru & 1821 & 0.16 & 0.24 \\
\hline Uruguay & 1811 & 0.14 & 0.07 \\
\hline Venezuela & 1830 & 0.12 & 0.59 \\
\hline \multicolumn{4}{|l|}{ North America } \\
\hline Canada * & 1867 & 1.28 & 1.94 \\
\hline United States * & 1783 & 18.93 & 21.41 \\
\hline \multicolumn{4}{|l|}{ Oceania } \\
\hline Australia * & 1901 & 0.91 & 1.07 \\
\hline New Zealand * & 1907 & 0.21 & 0.17 \\
\hline \multicolumn{2}{|c|}{ Total Sample: 64 countries } & 93.5 & 89.9 \\
\hline
\end{tabular}

\section{Appendix II: Domestic debt data}

The central government debt data assembled in this study is both broad in its cross-country coverage and spans nearly one-hundred years for most countries (1914 to 
2007) and even longer for many others. ${ }^{28}$ Here we present a synopsis of "state-of-theart” information on public debt (available data, sources, scope, etc.). We also highlight some of the salient characteristics of the long time series we study, in addition to what we have already discussed in section II of the text. ${ }^{29}$

\section{Data preliminaries}

Government debt is among the most elusive of economic time series.

For the advanced economies, the most comprehensive data comes from the OECD, which provides time series on general government debt since 1980. However, this data has several important limitations: it only includes a handful of emerging markets; for many advanced economies (France, Finland, Greece, and the U.K., to name a few) the data actually begins much later (in the 1990s), which cannot be considered as much of a time series; and only total debt is reported, with no particulars provided for the composition of debt (domestic versus foreign) or its maturity (long-term versus shortterm). To state that the IMF's well-known World Economic Outlook (WEO) database extends to public debt requires a stretch of the imagination. ${ }^{30}$ Data is only provided for the G-7 from 1980 onwards (out of 183 countries covered in the WEO).

The most comprehensive data on public debt in emerging market economies comes from the World Bank’s Global Development Finance-GDF (known previously as the World Debt Tables). It is an improvement on other databases in that it begins (for most countries) in 1970 and provides extensive detail on the particulars of external debt.

\footnotetext{
${ }^{28}$ The regional coverage is, unfortunately, uneven: coverage of Africa is relatively sparse (although we incorporate some excellent data from colonial records); it is, of course, most complete for Europe, North America, and Oceania.

${ }^{29}$ For compete references underlying this appendix and its accompanying database, see Reinhart and Rogoff (2008).

${ }^{30}$ This description comes from the IMF's web site "Download time series data for GDP growth, inflation, unemployment, payments balances, exports, imports, external debt, capital flows, commodity prices, more.”
} 
Yet, GDF also has serious limitations, besides the fact that it covers only external debt. Neither advanced economies are included to facilitate comparisons, nor are such newly industrialized countries as Israel, Korea, or Singapore. Unlike data from the IMF and the World Bank for exchange rates, prices, government finances, etc., there is no data prior to 1970. For a few countries, such as Panama or Cote D’Ivoire, external debt is a sufficient statistic on government liabilities, because domestic public debt levels are relatively trivial. For most countries, however, domestic debt accounts for an important share of total government debt. As we have already noted in the text, the all-country average oscillates between 40 to 80 percent during 1900 to $2006 .{ }^{31}$

In search of the elusive data on total public debt, we examined the archives of the League of Nations and found that the institution collected information on, among other things, public domestic and external debt in its Statistical Yearbook (1926-1944). While neither the IMF nor the World Bank continued this practice after the war, the newly formed United Nations (UN) inherited the data collected by the League of Nations. In 1948, the UN Department of Economic Affairs published a special volume on public debt that spanned 1914 to 1946 . From that time onwards, the UN continued to collect and publish the domestic and external debt data in the same format as their prewar predecessor on an annual basis in their Statistical Yearbooks. As former colonies became independent nations, the database expanded accordingly. This practice continued until 1983, at which time the domestic and external public debt series were discontinued. In total, these sources yield time series that span 1914 to 1983 for the most complete cases. It covers advanced and developing economies. For the most part, it also disaggregates

\footnotetext{
${ }^{31}$ For some countries, such as the Netherlands, Singapore, and the United States, practically all public debt is domestic.
} 
domestic debt into its long-term and short-term components. To the best of our knowledge, these data are not available electronically in any database. Hence obtaining it required going to the original publications. These data provide the starting point for our public debt series, which have been extended to the period prior to 1914 and post 1983 whenever possible. The sources are numerous. The material comes from large-scale historical statistical compendiums (such as Carreras and Tafunell, 2005, Estadísticas Históricas de España, Siglos XIX-XX) or from individual scholars (for example, Bazant's, 1968, careful study of Mexico’s domestic and foreign debt, Historia de la Deuda Exterior de Mexico: 1823-1946). Colonial records were also a valuable source of information for pre-1914; country-specific statistical and government agencies provide data for the more recent period. ${ }^{32}$ Data Appendix IV provides details for the sources by country and time period. Foreign external debt is from Reinhart and Rogoff (2008).

\section{Appendix III: Crises dates}

Appendix Table1 defines the criteria as to what constitutes a domestic debt crisis.

Specifically, as with sovereign default it is defined as:

1. A failure to meet a principal or interest payment on the due date (or within the specified grace period). (These episodes also include instances where rescheduled debt is ultimately extinguished on less favorable terms.)

2. The freezing of bank deposits and or forcible conversions of such deposits from dollars to local currency.

3. The abrogation of indexation clauses, as the United States did in the 1930s and as Argentina is doing at the time of this writing in 2008.

\footnotetext{
${ }^{32}$ For Australia, Ghana, India, Korea, South Africa among others, we have put together debt data for much of the colonial period from British statistical sources which tracked the colonies. We also have similar colonial data for former Japanese colonies.
} 
To our knowledge, this is the first effort to chronicle systematically sovereign defaults on

domestic debts, along the lines that economic historians have documented external

sovereign defaults. The closest source comparable to these dates on domestic sovereign

default is Standard and Poor's. 33

For a detailed description of all other data used in this study by country and by

year see Reinhart and Rogoff (2008).

\begin{tabular}{|c|c|c|}
\hline \multicolumn{3}{|c|}{ Appendix Table 2. Defining Debt Crises by Events: A Summary } \\
\hline Type of Crisis & Definition and or Criteria & Comments \\
\hline $\begin{array}{l}\text { Debt crises: } \\
\text { External }\end{array}$ & $\begin{array}{l}\text { A sovereign default is defined as the } \\
\text { failure to meet a principal or interest } \\
\text { payment on the due date (or within the } \\
\text { specified grace period). The episodes } \\
\text { also include instances where } \\
\text { rescheduled debt is ultimately } \\
\text { extinguished in terms less favorable } \\
\text { than the original obligation. }\end{array}$ & $\begin{array}{l}\text { While the time of default is accurately } \\
\text { classified as a crisis year there are a large } \\
\text { number of cases where the final resolution } \\
\text { with the creditors (if it ever did take place) } \\
\text { seems interminable. For this reason we also } \\
\text { work with a crisis dummy that only picks up } \\
\text { the first year. }\end{array}$ \\
\hline $\begin{array}{l}\text { Debt crisis: } \\
\text { Domestic }\end{array}$ & $\begin{array}{l}\text { The definition given above for external } \\
\text { debt applies. In addition, domestic debt } \\
\text { crises have involved the freezing of } \\
\text { bank deposits and or forcible } \\
\text { conversions of such deposits from } \\
\text { dollars to local currency. }\end{array}$ & $\begin{array}{l}\text { There is at best some partial documentation } \\
\text { of recent defaults on domestic debt provided } \\
\text { by Standard and Poor's. Historically, it is } \\
\text { very difficult to date these episodes and in } \\
\text { many cases (such as banking crises), it is } \\
\text { impossible to ascertain the date of the final } \\
\text { resolution. }\end{array}$ \\
\hline
\end{tabular}

\footnotetext{
${ }^{33}$ See the careful analysis of Beers and Chambers, Sovereign Defaults At 26-Year Low, To Show Little Change In 2007, which covers domestic default post-1975. Since this study is focused only on domestic public debt, it does miss some key episodes, such as forcible conversions of foreign currency bank deposits. These episodes constitute defaults on domestic debt because, typically, the government simultaneously writes down the value of treasury debt held by banks.
} 
Appendix Table 3. Episodes of Domestic Debt Default or Restructuring, 1750-1920

\begin{tabular}{|c|c|c|}
\hline Country & Dates & Commentary \\
\hline Argentina & 1890 & $\begin{array}{l}\text { This default also extended to several so-called } \\
\text { "internal" bonds. These bonds although not issued } \\
\text { in London, were denominated in a foreign currency } \\
\text { (£s) and marketed abroad-the forerunners of the } \\
\text { Mexican Tesobonos of the 1990s. }\end{array}$ \\
\hline China & March 1921 & $\begin{array}{l}\text { Consolidated internal debt plan to deal with the } \\
\text { arrears on most government bonds since } 1919 .\end{array}$ \\
\hline Denmark & January 1813 & $\begin{array}{l}\text { During the crisis, foreign debts were serviced but } \\
\text { domestic debt was reduced by } 39 \text { percent. }\end{array}$ \\
\hline Mexico & November 30, 1850 & $\begin{array}{l}\text { After the restructuring of foreign debt in October of } \\
\text { that year, domestic debt was roughly cut in half. } \\
\text { Domestic debt accounted for } 60 \text { percent of total } \\
\text { public debt. }\end{array}$ \\
\hline Peru & 1850 & $\begin{array}{l}\text { Domestic colonial debts were not cancelled—debt } \\
\text { prices collapsed and this debt was only restructured } \\
\text { in } 1850 \text {. }\end{array}$ \\
\hline Russia & December 1917-October 1918 & $\begin{array}{l}\text { Repudiation of debts and confiscation of gold in all } \\
\text { forms followed by confiscation of all foreign } \\
\text { exchange. }\end{array}$ \\
\hline United Kingdom & $1749,1822,1834,1888-89$ & $\begin{array}{l}\text { Among several conversions of debt into lower } \\
\text { coupon rates. Reductions in rates were mostly } 0.5- \\
1.0 \text { percent in these episodes. }\end{array}$ \\
\hline United States & January 1790 & $\begin{array}{l}\text { Nominal interest was maintained at } 6 \text { percent, but a } \\
\text { portion of the interest was deferred for } 10 \text { years. }\end{array}$ \\
\hline $\begin{array}{l}\text { United States ( } 9 \\
\text { states) }\end{array}$ & $1841-1842$ & Three states repudiated their debts altogether. \\
\hline $\begin{array}{l}\text { United States } \\
\text { (states and many } \\
\text { local } \\
\text { governments) }\end{array}$ & $1873-83$ or 1884 & $\begin{array}{l}\text { By } 1873,10 \text { states were in default. In the case of } \\
\text { West Virginia, settlement was as late as } 1919 .\end{array}$ \\
\hline
\end{tabular}


Appendix Table 3. Selected Episodes of Domestic Debt Default or Restructuring, 1930s-1950s

\begin{tabular}{|c|c|c|}
\hline Country & Dates & "Commentary \\
\hline Bolivia & 1927 & Arrears of interest lasted until at least 1940. \\
\hline Canada (Alberta) & April 1935 & $\begin{array}{l}\text { The only province to default-which lasted for about } 10 \\
\text { years. }\end{array}$ \\
\hline China & 1932 & $\begin{array}{l}\text { First of several “consolidations”, monthly cost of } \\
\text { domestic service was cut in half. Interest rates were } \\
\text { reduced to } 6 \text { percent (from over } 9 \text { percent)-amortization } \\
\text { periods were about doubled in length. }\end{array}$ \\
\hline Greece & 1932 & $\begin{array}{l}\text { Interest on domestic debt was reduced by } 75 \text { percent since } \\
\text { 1932; Domestic debt was about } 1 / 4 \text { of total public debt. }\end{array}$ \\
\hline Mexico & 1930s & $\begin{array}{l}\text { Service on external debt was suspended in 1928. During } \\
\text { the 1930s, interest payments included "arrears of } \\
\text { expenditure and civil and military pensions.” }\end{array}$ \\
\hline Peru & 1931 & $\begin{array}{l}\text { After suspending service on external debt on May 29, } \\
\text { Peru made "partial interest payments" on domestic debt. }\end{array}$ \\
\hline Romania & February 1933 & $\begin{array}{l}\text { Redemption of domestic and foreign debt is suspended } \\
\text { (except for three loans). }\end{array}$ \\
\hline Spain & October 1936-April 1939 & $\begin{array}{l}\text { Interest payments on external debt were suspended, } \\
\text { arrears on domestic debt service. }\end{array}$ \\
\hline United States & 1933 & $\begin{array}{l}\text { Abrogation of the gold clause. In effect, the U.S. refused } \\
\text { to pay Panama the annuity in gold due to Panama } \\
\text { according to a } 1903 \text { treaty. The dispute was settled in } \\
1936 \text { when the US paid the agreed amount in gold } \\
\text { balboas. }\end{array}$ \\
\hline United Kingdom & 1932 & $\begin{array}{l}\text { Most of the outstanding WWI debt was consolidated into } \\
\text { a } 3.5 \text { percent perpetual annuity. }\end{array}$ \\
\hline Uruguay & $\begin{array}{l}\text { November 1, 1932-February, } \\
1937\end{array}$ & $\begin{array}{l}\text { After suspending redemption of external debt on January } \\
20 \text {, redemptions on domestic debt were equally } \\
\text { suspended. }\end{array}$ \\
\hline Austria & December 1945 & $\begin{array}{l}\text { Restoration of schilling ( } 150 \text { limit per person). Remainder } \\
\text { placed in blocked accounts. In December 1947, large } \\
\text { amounts of previously blocked schillings invalidated and } \\
\text { rendered worthless. Temporary blockage of } 50 \text { percent of } \\
\text { deposits. }\end{array}$ \\
\hline Germany & June 20, 1948 & $\begin{array}{l}\text { Monetary reform limiting } 40 \text { Deutschemark per person. } \\
\text { Partial cancellation and blocking of all accounts. }\end{array}$ \\
\hline Japan & March 2, 1946-1952 & $\begin{array}{l}\text { After inflation, exchange of all bank notes for new issue } \\
\text { (1 to } 1 \text { ) limited to } 100 \text { yen per person. Remaining } \\
\text { balances were deposited in blocked accounts. }\end{array}$ \\
\hline \multirow[t]{2}{*}{ Russia } & 1947 & $\begin{array}{l}\text { The monetary reform subjected privately held currency to } \\
\text { a } 90 \text { percent reduction. }\end{array}$ \\
\hline & April 10, 1957 & $\begin{array}{l}\text { Repudiation of domestic debt (about } 253 \text { billion rubles at } \\
\text { the time). }\end{array}$ \\
\hline
\end{tabular}


Appendix Table 3. Selected Episodes of Domestic Debt Default or Restructuring, 1970-2007 (concluded)

\begin{tabular}{|c|c|c|}
\hline Country & Dates & "Commentary \\
\hline \multicolumn{3}{|c|}{ Africa } \\
\hline Angola & 1976, 1992-2002 & \\
\hline Cameroon & 2004 & \\
\hline Congo (Kinshasa) & 1979 & \\
\hline Gabon & 1999-2005 & \\
\hline Ghana & 1979, 1982 & $\begin{array}{l}\text { Default on central bank notes (in the context of } \\
\text { conversion to a new currency). }\end{array}$ \\
\hline Liberia & 1989-2006 & \\
\hline Madagascar & 2002 & \\
\hline Mozambique & 1980 & \\
\hline Rwanda & 1995 & No external default. \\
\hline Sierra Leone & 1997-1998 & \\
\hline Sudan & 1991 & \\
\hline \multicolumn{3}{|c|}{ Asia } \\
\hline Mongolia & 1997-2000 & \\
\hline Myanmar & 1984, 1987 & \\
\hline Sri Lanka & 1996 & No external default. \\
\hline Solomon Islands & 1995-2004 & \\
\hline Vietnam & 1975 & \\
\hline \multicolumn{3}{|c|}{ Europe and the Middle East } \\
\hline Croatia & 1993-1996 & \\
\hline Kuwait & 1990-1991 & \\
\hline Russia & 1998-1999 & $\begin{array}{l}\text { Largest local currency debt default (US } \$ 39 \text { billion) since } \\
\text { Brazil } 1990 .\end{array}$ \\
\hline Ukraine & \multicolumn{2}{|c|}{ Western Hemisphere } \\
\hline $\begin{array}{l}\text { Antigua and } \\
\text { Barbuda }\end{array}$ & 1998-2005 & \\
\hline Argentina & 1982, 1989-90, 2002-2005 & Forcible conversion of U.S. dollar debt to peso debt. \\
\hline Bolivia & 1982 & $\begin{array}{l}\text { U.S. dollar deposits were forcibly converted into local } \\
\text { currency. Foreign currency deposits were again allowed } \\
\text { in } 1985 \text { as part of the stabilization plan when capital } \\
\text { controls were lifted. }\end{array}$ \\
\hline Brazil & 1986-87, 1990 & $\begin{array}{l}\text { Abrogation of inflation-linked indices embedded in the } \\
\text { original contracts. Largest default (US\$ } 62 \text { billion) in } \\
1990 .\end{array}$ \\
\hline Dominica & 2003-2005 & \\
\hline Dominican Republic & 1975-2001 & \\
\hline Ecuador & 1999 & \\
\hline El Salvador & 1981-1996 & $\begin{array}{l}\text { The only case in Latin America where there was a default } \\
\text { in domestic debt that was NOT accompanied by external } \\
\text { default. }\end{array}$ \\
\hline Grenada & 2004-2005 & \\
\hline Mexico & 1982 & Forcible conversion of dollar deposits to pesos. \\
\hline Panama & 1988-1989 & $\begin{array}{l}\text { Arrears in domestic suppliers' credit, wages, and civil and } \\
\text { military pensions. }\end{array}$ \\
\hline Peru & 1985 & $\begin{array}{l}\text { U.S. dollar deposits were forcibly converted into local } \\
\text { currency. Foreign currency deposits were allowed again } \\
\text { in } 1988 \text {. }\end{array}$ \\
\hline Surinam & 2001-2002 & \\
\hline Venezuela & 1995-1997, 1998 & \\
\hline Zimbabwe & 2006 & $\begin{array}{l}\text { With over } 98.5 \text { percent of domestic debt with maturities } \\
\text { less than a year, there is a restructuring. }\end{array}$ \\
\hline
\end{tabular}


Appendix Figure 1 plots for the years 1900-2006 (where our data set is most complete) the percentage of all independent countries in a state of default or restructuring on domestic sovereign debt during any given year. One fact that jumps out from the figure are the two long periods where a higher percentage of all countries are in a state of default or restructuring. Like banking crises (see Reinhart and Rogoff, 2008), domestic debt crises are bunched during the Great Depression of the 1930s and debt crises which began in the early 1980s.

\section{Appendix Figure 1}

Sovereign Domestic De6t: 1900-2006 Percent of countries in Default or Restructuring

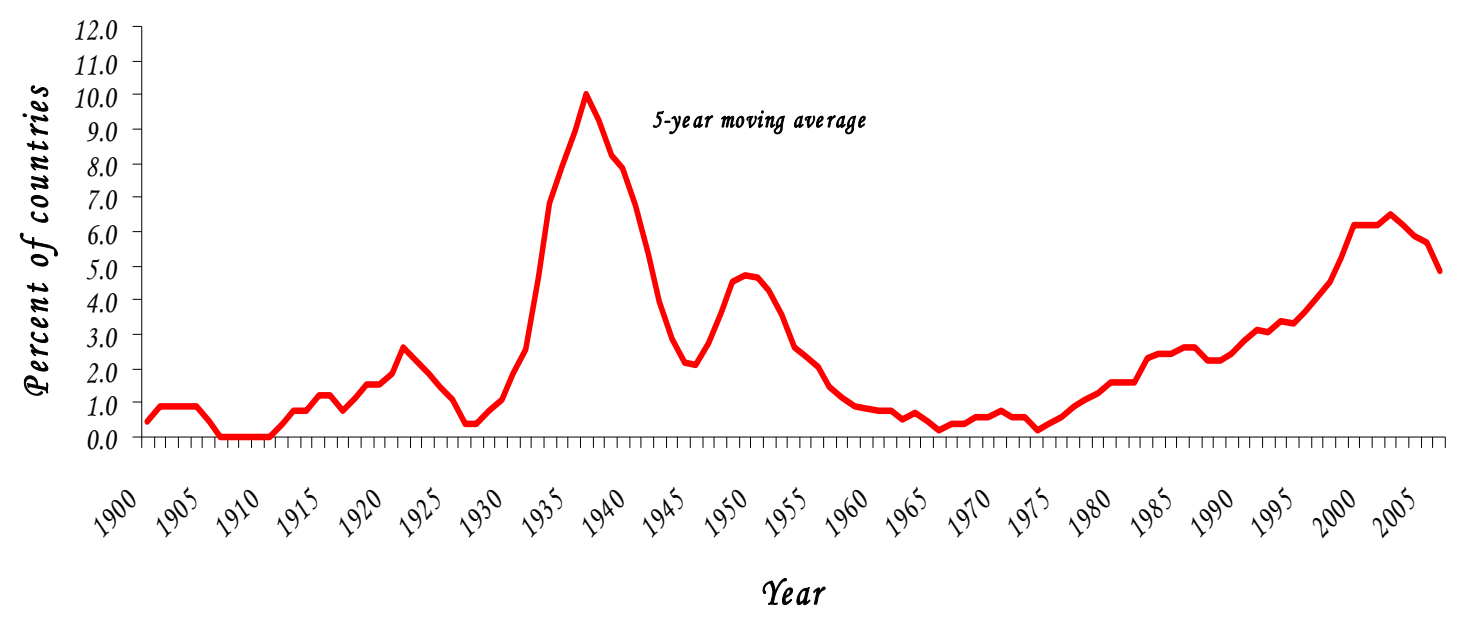




\section{Appendix IV. Public Debt: Detailed Sources}

This data appendix covers the government debt series used, while Appendix I is devoted to the database on macro time series.

Abbreviations of frequently used sources (additional sources listed in tables below):

CLYPS: Cowan, Levy-Yeyati, Panizza, Sturzenegger

ESFDB: European State Finance Data Base

GFD: Global Financial Data, The World Bank

IFS: International Financial Statistics, IMF.

LM: Lindert \& Morton

LofN: League of Nations

MAR: Marichal

MIT: Mitchell

RR: Reinhart and Rogoff

UN: United Nations

WEO: World Economic Outlook, IMF

Lcu: local currency units 
Appendix Table 4 Domestic Public Debt (Local currency units unless otherwise noted)

\begin{tabular}{|c|c|c|c|}
\hline Country & Period covered & Source & Commentary \\
\hline \multirow[t]{3}{*}{ Argentina } & $1863-1971$ & Garcia Vizcaino & Lcu \\
\hline & $1914-1981$ & LofN/UN & Lcu \\
\hline & 1980-2005 & GFD, Jeanne \& Guscina & \\
\hline \multirow[t]{2}{*}{ Australia } & $1914-1981$ & LofN/UN & Lcu \\
\hline & $1980-2007$ & $\begin{array}{l}\text { Australian Office of } \\
\text { Financial Management }\end{array}$ & Lcu \\
\hline \multirow[t]{2}{*}{ Austria } & 1945-1984 & UN & Lcu \\
\hline & 1970-2006 & $\begin{array}{l}\text { Austrian Federal } \\
\text { Financing Agency }\end{array}$ & euros \\
\hline \multirow[t]{2}{*}{ Belgium } & 1914-1983 & LofN/UN & Lcu \\
\hline & 1992-2007 & $\begin{array}{l}\text { BNB, Centre d'études } \\
\text { économiques de la KUL }\end{array}$ & \\
\hline \multirow[t]{3}{*}{ Bolivia } & 1914-1953 & LofN/UN & Lcu \\
\hline & 1968-1981 & & \\
\hline & 1991-2004 & CLYPS & US\$ \\
\hline \multirow[t]{2}{*}{ Brazil } & 1923-1972 & LofN/UN & Lcu \\
\hline & $1991-2005$ & GFD, Jeanne \& Guscina & \\
\hline Canada & $1867-2007$ & $\begin{array}{l}\text { Statistics Canada, Bank } \\
\text { of Canada }\end{array}$ & Lcu \\
\hline \multirow[t]{4}{*}{ Chile } & $1827-2000$ & Diaz et al. & Lcu \\
\hline & $1914-1953$ & LofN/UN & Lcu \\
\hline & 1914-1946 & UN & \\
\hline & $1990-2007$ & Ministerio de Hacienda & US\$ \\
\hline China & 1894-1949 & $\begin{array}{l}\text { RR (from Cheng, } \\
\text { Huang, UN) }\end{array}$ & Lcu \\
\hline Colombia & 1923-2006 & $\begin{array}{l}\text { Contraloria General de } \\
\text { la Republica }\end{array}$ & Lcu \\
\hline \multirow[t]{3}{*}{ Costa Rica } & 1892-1914 & Soley-Guell & Lcu \\
\hline & $1914-1983$ & LofN/UN & Lcu \\
\hline & 1980-2007 & $\begin{array}{l}\text { CLYPS, Ministerio de } \\
\text { Hacienda }\end{array}$ & US\$ \\
\hline Cote D'Ivoire & 1970-1980 & UN & Lcu \\
\hline \multirow[t]{2}{*}{ Denmark } & 1914-1975 & LofN/UN & Lcu \\
\hline & 1990-2007 & $\begin{array}{l}\text { Denmark’s National } \\
\text { Bank }\end{array}$ & Lcu \\
\hline Dominican Republic & $1914-1952$ & LofN/UN & Lcu \\
\hline \multirow[t]{2}{*}{ Ecuador } & $1914-1972$ & LofN/UN & Lcu \\
\hline & 1990-2006 & Ministry of Finance & US\$ \\
\hline \multirow[t]{2}{*}{ Egypt } & $1914-1959$ & LofN/UN & Lcu \\
\hline & 2001-2005 & Ministry of Finance & Lcu \\
\hline
\end{tabular}


Appendix Table 4. Domestic Public Debt, continued (Local currency units unless otherwise noted)

\begin{tabular}{|c|c|c|c|}
\hline Country & Period covered & Source & Commentary \\
\hline \multirow[t]{2}{*}{ France } & $1913-1972$ & LofN/UN & Lcu \\
\hline & 1999-2007 & $\begin{array}{l}\text { Ministère du Budget, } \\
\text { des comptes public }\end{array}$ & Lcu \\
\hline \multirow[t]{2}{*}{ Greece } & 1920-1983 & LofN/UN & Lcu \\
\hline & $1912-1941$ & UN & \\
\hline \multirow[t]{2}{*}{ Guatemala } & 1921-1982 & LofN/UN & Lcu \\
\hline & 1980-2005 & CLYPS & US\$ \\
\hline \multirow[t]{2}{*}{ Honduras } & 1914-1971 & LofN/UN & Lcu \\
\hline & 1980-2005 & & US\$ \\
\hline \multirow[t]{2}{*}{ Hungary } & 1913-1942 & LofN/UN & Lcu \\
\hline & 1992-2005 & Jeanne \& Guscina & \\
\hline \multirow[t]{3}{*}{ India } & $1840-1920$ & $\begin{array}{l}\text { Statistical Abstract } \\
\text { relating to British India }\end{array}$ & \\
\hline & 1913-1983 & LofN/UN & Lcu \\
\hline & 1980-2005 & Jeanne \& Guscina & \\
\hline \multirow[t]{2}{*}{ Indonesia } & 1972-1983 & UN & Lcu \\
\hline & 1998-2005 & Bank Indonesia/GFD & \\
\hline \multirow[t]{3}{*}{ Italy } & 1880-1913 & Flandreau \& Zumer & Lcu \\
\hline & 1914-1894 & LofN/UN & Lcu \\
\hline & $1882-2007$ & $\begin{array}{l}\text { Dipartamento del } \\
\text { Tesoro }\end{array}$ & Lcu \\
\hline \multirow[t]{2}{*}{ Japan } & 1872-2007 & $\begin{array}{l}\text { Historical Statistics of } \\
\text { Japan/Bank of Japan }\end{array}$ & Lcu \\
\hline & 1914-1946 & UN & \\
\hline \multirow{2}{*}{ Kenya } & 1961-1980 & LofN/UN & Lcu \\
\hline & 1997-2007 & Central Bank of Kenya & Lcu \\
\hline \multirow{2}{*}{ Korea } & 1970-1984 & LofN/UN & Lcu \\
\hline & 1990-2004 & Jeanne \& Guscina & Lcu \\
\hline \multirow[t]{3}{*}{ Malaysia } & 1947-1957 & LofN/UN & Lcu \\
\hline & 1976-1981 & & \\
\hline & 1980-2004 & Jeanne \& Guscina & \\
\hline \multirow{2}{*}{ Mauritius } & 1970-1984 & LofN/UN & Lcu \\
\hline & 1998-2007 & Bank of Mauritius & Lcu \\
\hline \multirow[t]{3}{*}{ Mexico } & 1814-1946 & Bazant & Not continuous \\
\hline & 1914-1979 & LofN/UN & Lcu \\
\hline & 1980-2006 & $\begin{array}{l}\text { Direccion General de la } \\
\text { Deuda Publica }\end{array}$ & \\
\hline Morocco & 1965-1980 & UN & Lcu \\
\hline \multirow[t]{3}{*}{ Netherlands } & 1880-1914 & Flandreau \& Zumer & Lcu \\
\hline & 1914-1977 & LofN/UN & Lcu \\
\hline & 1914-2008 & $\begin{array}{l}\text { Dutch State Treasury } \\
\text { Agency }\end{array}$ & Lcu \\
\hline
\end{tabular}


Appendix Table 4. Domestic Public Debt, continued (Local currency units unless otherwise noted)

\begin{tabular}{|c|c|c|c|}
\hline Country & Period covered & Source & Commentary \\
\hline New Zealand & 1858-2006 & $\begin{array}{l}\text { Statistics New } \\
\text { Zealand/NZ Treasury }\end{array}$ & Lcu \\
\hline Nicaragua & $\begin{array}{l}1914-1945 \\
1970-1983\end{array}$ & LofN/UN & Lcu \\
\hline & 1991-2005 & CLYPS & US\$ \\
\hline Norway & $\begin{array}{l}1880-1914 \\
1913-1983\end{array}$ & $\begin{array}{l}\text { Flandreau \& Zumer } \\
\text { LofN/UN }\end{array}$ & $\begin{array}{l}\text { Lcu } \\
\text { Lcu }\end{array}$ \\
\hline & 1965-2007 & Ministry of Finance & Lcu \\
\hline Panama & $\begin{array}{l}1915-1983 \\
1980-2005\end{array}$ & $\begin{array}{l}\text { LofN/UN } \\
\text { CLYPS }\end{array}$ & $\begin{array}{l}\text { US\$ } \\
\text { US\$ }\end{array}$ \\
\hline Paraguay & $\begin{array}{l}1927-1947 \\
1976-1982\end{array}$ & LofN/UN & Lcu \\
\hline & 1990-2004 & CLYPS & US\$ \\
\hline Peru & $\begin{array}{l}1918-1970 \\
1990-2005\end{array}$ & $\begin{array}{l}\text { LofN/UN } \\
\text { CLYPS }\end{array}$ & $\begin{array}{l}\text { Lcu } \\
\text { US\$ }\end{array}$ \\
\hline Philippines & $\begin{array}{l}1948-1982 \\
1980-2005\end{array}$ & $\begin{array}{l}\text { LofN/UN } \\
\text { GFD, Jeanne \& Guscina }\end{array}$ & Lcu \\
\hline Poland & $\begin{array}{l}1920-1947 \\
1994-2004\end{array}$ & $\begin{array}{l}\text { LofN/UN } \\
\text { Jeanne \& Guscina }\end{array}$ & $\begin{array}{l}\text { Lcu } \\
\text { Lcu }\end{array}$ \\
\hline Portugal & $1851-1997$ & $\begin{array}{l}\text { INE-Portugese } \\
\text { Statistical Agency }\end{array}$ & Lcu \\
\hline & $\begin{array}{l}1914-1975 \\
1980-2007\end{array}$ & $\begin{array}{l}\text { LofN/UN } \\
\text { Banco de Portugal }\end{array}$ & $\begin{array}{l}\text { Lcu } \\
\text { In euros from } 1999\end{array}$ \\
\hline Russia & $\begin{array}{l}1922-1938 \\
1993-2005\end{array}$ & $\begin{array}{l}\text { LofN/UN } \\
\text { Jeanne \& Guscina }\end{array}$ & $\mathrm{Lcu}$ \\
\hline Singapore & $\begin{array}{l}1969-1982 \\
1986-2006\end{array}$ & $\begin{array}{l}\text { UN } \\
\text { Monetary Authority }\end{array}$ & $\begin{array}{l}\text { Lcu } \\
\text { Lcu }\end{array}$ \\
\hline South Africa & $\begin{array}{l}1859-1914 \\
1910-1983 \\
1946-2006\end{array}$ & $\begin{array}{l}\text { Page } \\
\text { LofN/UN } \\
\text { South Africa Reserve } \\
\text { Bank }\end{array}$ & $\begin{array}{l}\text { UK pounds } \\
\text { Lcu } \\
\text { Lcu }\end{array}$ \\
\hline Spain & 1850-2001 & $\begin{array}{l}\text { Estadisticas Historicas } \\
\text { de España: Siglos XIX- } \\
\text { XX }\end{array}$ & Lcu \\
\hline & 1999-2006 & Banco de España & Euro \\
\hline Sri Lanka & $\begin{array}{l}1950-1983 \\
1990-2006\end{array}$ & $\begin{array}{l}\text { UN } \\
\text { Central Bank of Sri } \\
\text { Lanka }\end{array}$ & $\begin{array}{l}\text { Lcu } \\
\text { Lcu }\end{array}$ \\
\hline
\end{tabular}


Appendix Table 4. Domestic Public Debt, concluded (Local currency units unless otherwise noted)

\begin{tabular}{llll}
\hline \hline Country & Period covered & Source & Commentary \\
& & & \\
\hline Sweden & $1914-1984$ & LofN/UN & Lcu \\
& $1950-2006$ & Riksgälden & Lcu \\
Thailand (Siam) & $1913-1984$ & $\begin{array}{l}\text { LofN/UN } \\
\text { Jeanne \& Guscina, Bank } \\
\text { of Thailand }\end{array}$ & Lcu \\
& $1980-2006$ & & \\
& & UN & Lcu \\
Tunisia & $1972-1982$ & Central Bank of Tunisia & Lcu \\
& $2004-2007$ & LofN/UN & Lcu \\
Turkey & $1933-1984$ & Turkish Treasury & US\$ \\
& $1986-2007$ & LofN/UN & Lcu \\
United Kingdom & $1914-2007$ & Treasury Direct & Lcu \\
United States & $1791-2007$ & LofN/UN & Lcu \\
Uruguay & $1914-1947$ & CLYPS & US\$ \\
& $1972-1984$ & LofN/UN & Lcu \\
Venezuela & $1980-2004$ & Jeanne \& Guscina & Lcu \\
& $1914-1982$ & UN & Lcu \\
\hline \hline
\end{tabular}

